NBER WORKING PAPER SERIES

\title{
WHEN DOES DOMESTIC SAVING MATTER FOR ECONOMIC GROWTH?
}

\author{
Philippe Aghion \\ Diego Comin \\ Peter Howitt \\ Working Paper 12275 \\ http://www.nber.org/papers/w12275
NATIONAL BUREAU OF ECONOMIC RESEARCH 1050 Massachusetts Avenue
Cambridge, MA 02138
May 2006

\begin{abstract}
We would like to thank the comments and suggestions of Daron Acemoglu, Pol Antras, Tim Besley, Raquel Fernandez, Mark Gertler, Avner Greif, Elhanan Helpman, Greg Mankiw, Joel Mokyr, Fabrizio Perri, and seminar participants at Harvard and Stern, and the excellent research assistance of Juan Diego Bonilla and Victor Tsyrennikov. The views expressed herein are those of the author(s) and do not necessarily reflect the views of the National Bureau of Economic Research.

(C2006 by Philippe Aghion, Diego Comin and Peter Howitt. All rights reserved. Short sections of text, not to exceed two paragraphs, may be quoted without explicit permission provided that full credit, including $($ ) notice, is given to the source.
\end{abstract}


When Does Domestic Saving Matter for Economic Growth?

Philippe Aghion, Diego Comin and Peter Howitt

NBER Working Paper No. 12275

May 2006, Revised September 2006

JEL No. E2, O2, O3

\begin{abstract}
$\underline{\text { ABSTRACT }}$
Can a country grow faster by saving more? We address this question both theoretically and empirically. In our model, growth results from innovations that allow local sectors to catch up with the frontier technology. In relatively poor countries, catching up with the frontier requires the involvement of a foreign investor, who is familiar with the frontier technology, together with effort on the part of a local bank, who can directly monitor local projects to which the technology must be adapted. In such a country, local saving matters for innovation, and therefore growth, because it allows the domestic bank to cofinance projects and thus to attract foreign investment. But in countries close to the frontier, local firms are familiar with the frontier technology, and therefore do not need to attract foreign investment to undertake an innovation project, so local saving does not matter for growth. In our empirical exploration we show that lagged savings is significantly associated with productivity growth for poor but not for rich countries. This effect operates entirely through TFP rather than through capital accumulation. Further, we show that savings is significantly associated with higher levels of FDI inflows and equipment imports and that the effect that these have on growth is significantly larger for poor countries than rich.
\end{abstract}

Philippe Aghion

Department of Economics

Harvard University

Cambridge, MA 02138

and NBER

paghion@fas.harvard.edu

Diego A. Comin

Department of Economics

New York University

269 Mercer Street, 725

New York, NY 10003

and NBER

diego.comin@nyu.edu

Peter Howitt

Department of Economics

Brown University, Box B

Providence, RI 02912

and NBER

peter howitt@brown.edu 


\section{Introduction}

Can a country grow faster by saving more? The relationship between saving and growth plays a central role in the neoclassical growth models of Solow (1956) and Cass (1965), Koopmans (1965) and Ramsey (1928). It also features prominently in the AK models starting with Harrod (1939) and Domar (1946), and then more recently by Frankel (1962) and Romer (1986). All these growth models emphasizing capital accumulation as the source of growth, tell us indeed that higher saving rates should foster growth because higher savings imply higher capital investment. But these are closed economy models, and extending them to the case of small open economies with international capital markets would eliminate the effect of local saving on growth. More recent models emphasizing innovation as the main engine of growth (Romer, 1990; and Aghion and Howitt, 1992), either ignore capital accumulation, in which case there is no role for saving even in a closed economy, or they emphasize the complementarity between capital accumulation and innovation (Howitt and Aghion, 1998), in which case the equilibrium growth rate depends positively upon domestic saving. But even in the latter case the theory does not apply to the case of an open economy with capital mobility.

Thus existing growth theories appear to have little to say about the effect of saving on growth in the global economy, and yet this question is raised recurrently by policy makers, for example when discussing the contrast between the high growth in East Asia and the slow growth in Latin America, two middle-income regions with comparable levels of per capita GDP in the 1960s. This contrast could hardly be explained by differences in property right protection or in financial development. Moreover, most Latin American countries have subscribed to the so-called Washington consensus policies (namely, the idea of combining macroeconomic stability, trade and financial liberalization, and privatization), but so far to little avail. On the other hand, if one looks at saving rates in the two regions, we do see a sizeable difference, with East Asian rates being much higher than Latin American rates. Specifically, for the East Asian countries in the sample described in Section 4 below the average private saving rate from 1960 to 2000 was 25\%, whereas for Latin American countries in the same sample the average saving rate was only $14 \%{ }^{1}$

In this paper, we develop a theory of local saving and growth in an open economy with domestic and foreign investors. In our model, growth in relatively poor countries results mainly from innovations that allow local sectors to catch up with the current frontier technology. But catching up with the frontier in any sector requires the involvement of a foreign investor, who is familiar with the frontier technology, together with effort on the part of a local bank, who can directly monitor local projects to which the technology must be adapted. Local saving matters for innovation, and therefore growth, because it allows the domestic bank to cofinance projects and thus to attract foreign investment; more specifically, cofinancing encourages local bank monitoring effort by giving the local bank a stake that it will lose if the project fails for want of effort on its part, and therefore raises the expected rate of return to the foreign investor.

\footnotetext{
${ }^{1}$ One exception in terms of growth performance in Latin America has been Chile. The average growth rate of GDP per worker in Chile between 1960 and 2000 has been almost 2 percent a year. Interestingly, its average saving rate has been 20 percent. See Prescott (2006) for more on the role of savings in the positive growth experience of Chile.
} 
The theory also delivers predictions on when domestic saving should matter most for economic growth. In particular it focuses on the interaction between saving and the country's distance to the technological frontier. The main prediction of our model is that saving affects growth positively in those countries that are not too close to the technological frontier, but does not affect it at all in countries that are close to the frontier. The reason is that in a relatively poor country higher saving increases the number of projects that can be cofinanced by the local bank on terms that give the bank an incentive to monitor while guaranteeing a sufficient share of profits for a foreign investor to participate. However, in countries sufficiently close to the frontier the local firms are more likely themselves to be familiar with the frontier technology, and therefore do not need to attract foreign investment in order to undertake an innovation project; in such a case every ex ante profitable innovation project will be undertaken regardless of the level of domestic saving because there is no need for cofinance when there is just one agent participating in the project.

In the second part of the paper, we confront the above theory with empirical evidence. Houthakker (1961, 1965), Modigliani (1970) and Carroll and Weil (1994) have shown that there is a large and highly significant positive correlation between saving and growth in the cross-section of countries. However, there is little agreement as to how one should interpret this correlation. Given the difficulty of providing a causal link from saving to growth in a world of capital mobility, several observers have sought to explain the correlation as reflecting an effect of growth on saving. But this interpretation runs counter to mainstream economic theory in which the representative household's consumption-Euler equation implies that growth should have a negative effect on saving. Thus for example Carroll, Overland and Weil (2000) depart from convention by developing a model of habit persistence which they argue is consistent with a wide body of evidence to the effect that increases in growth precede increases in saving.

In our empirical exploration we provide evidence of the causal link running from saving to growth, namely the one that our theory implies should operate even in a world of capital mobility. We first explore various case studies of Asian countries. In the growth episodes of these countries, we observe the importance of policies that tried to increase private savings to provide liquidity to the banking system. Further, the liquidity of the domestic banking system helped attract foreign investors that brought in the frontier technology that triggered TFP and productivity growth. After this informal exploration, we explore econometrically the reduced form predictions of the model and its mechanisms. Specifically, using the within country variation in a panel of 118 countries over the 1960-2000 period, we show that the average saving rate in the last five years positively affects growth in productivity during the decade going forward in poor countries, while in rich countries the effect is smaller and often not significant. In line with the model, private saving is entirely responsible for the effect of saving on growth. Further, the connection between lagged saving and subsequent growth operates exclusively through TFP growth. This finding is relevant because it differentiates our model from others that emphasize a connection between saving and future investment through the financial accelerator (e.g. Bernanke and Gertler, 1989).

To gain further insight into the mechanisms that drive the connection between saving and growth, we explore the relationship between FDI, equipment imports, saving and growth. We find that lagged average saving is highly correlated with FDI and equipment import intensity, especially in poor countries where both FDI and equipment imports enter positive 
and significantly in the panel growth regressions. In addition, the inclusion of either FDI or equipment investment reduces significantly the estimated effect of lagged savings on the productivity growth and the TFP growth of poor countries but not in rich countries.

Cofinancing is formally equivalent to posting collateral. Dooley, Folkerts-Landau and Garber (2004) also stress the role of collateral in the growth process of some countries. Specifically, they argue that capital flows from poor to rich countries may partly reflect poor countries' choices to transfer wealth to a "center or reserve currency country" in order to make it easier for foreigners to get their hands on that wealth should the poor countries expropriate the foreigners' capital; this in turn should encourage foreign direct investment in poor countries, thereby fostering development. However, Dooley et al. do not explore this idea in the context of a full-fledged endogenous growth model. Nor do they analyze its implications for the relationship between local saving and growth across countries with different levels of technological development.

Our theory relates not only to the growth literature but also to an important debate in international finance around the so-called "Lucas puzzle", namely why poorer countries or regions, where capital is scarce and therefore the marginal productivity of capital should be high, do not attract investments that would make them converge towards the frontier countries or regions. Lucas (1990) points to the role of human capital externalities that would favor capital investments in richer countries. However, Gertler and Rogoff (1990), and more recently Banerjee and Duflo (2005), point to the importance of contractual imperfections (whether these result from local contractual enforcement problems or from ex ante moral hazard on the part on local investors). Gertler and Rogoff provide supporting evidence in favor of the contracting explanation, in particular the positive and significant correlation between the volume of private external debt and the log of per capita income in a crosscountry regression. More recent evidence in Alfaro et al (2003) to the effect that private lending by foreign investors is correlated with various institutional indicators, in particular with a lower degree of corruption, is consistent with the contracting explanation, as is the evidence in Reinhart and Rogoff (2004) that poorer countries exhibit a higher rate of defaults on their foreign debt. The relationship between financial constraints and foreign investment flows is also emphasized in recent work by Antras, Desai and Foley (2005) that explains why we observe large and two-way FDI flows between countries with high levels of development, whereas capital flows between countries with uneven degrees of financial development are small and unbalanced. Also closely related to our analysis in this paper is Alfaro et al (2004) which shows, based on a cross-country sample, that FDI is more positively correlated with growth in countries with higher financial development. Our paper contributes to this literature by developing an endogenous growth model that shows how local saving impacts on foreign investment and thereby on growth in an economy with contractual frictions, and by confronting the predictions of this model with cross-country panel data.

The paper is organized as follows. Section 2 develops a model embodying our theory and derives the prediction to the effect that saving has a positive effect on growth in all but the most technologically advanced countries. Section 3 discusses anecdotal evidence from East Asia. Section 4 presents our empirical evidence. Section 5 concludes. 


\section{A simple model}

\subsection{Basic environment}

We consider a discrete-time model of a small open economy, populated by two-period lived individuals. Individuals work and save when young to invest in innovation and consume when old, and we denote by $\sigma$ their saving rate when young. Instead of modelling saving as resulting from intertemporal utility maximization we simply take $\sigma$ as given.

A financial intermediary (a bank) can use local savings to attract foreign investment. (It cannot use foreign savings because of the difficulty that foreigners would have in monitoring the local bank.) The bank can monitor innovation projects, and we implicitly assume that it cannot monitor foreign projects; conversely, foreign banks financed with foreign savings are unable to monitor local projects.

There is a unique final good, which is produced using labor and a continuum of intermediate inputs, according to the production function:

$$
y_{t}=L^{1-\alpha} \int_{0}^{1} A_{i t}^{1-\alpha} x_{i t}^{\alpha} d i,
$$

where $L$ is the supply of labor, taken as an exogenous constant, and $A_{i t}$ is the productivity of the current input $i$ at time $t$.

Intermediate goods are produced by local monopolists, using final good as capital with one unit of capital producing one unit of intermediate input. The amount of intermediate input $x_{i t}$ is chosen by producer $i$ to maximize monopoly profits

$$
p_{i t} x_{i t}-x_{i t}
$$

subject to the inverse demand schedule

$$
p_{i t}=\frac{\partial y_{t}}{\partial x_{i t}}=\alpha\left(A_{i t} L / x_{i t}\right)^{1-\alpha},
$$

where the marginal cost of the intermediate good has been normalized to 1 . This yields

$$
x_{i t}=A_{i t} L\left(\alpha^{2}\right)^{\frac{1}{1-\alpha}} \equiv A_{i t} L \kappa,
$$

with equilibrium profits equal to

$$
\pi_{i t}=\alpha(1-\alpha) \kappa^{\alpha} L A_{i t} \equiv \theta A_{i t} .
$$

Moreover, assuming perfect competition in the labor market yields an equilibrium wage:

$$
w_{t}=(1-\alpha) \kappa^{\alpha} A_{t}=\omega A_{t} .
$$

where $A_{t}=\int_{0}^{1} A_{i t} d i$ is average productivity. ${ }^{2}$

\footnotetext{
${ }^{2}$ Substituting from the above expression for $x_{i t}$ back into the aggregate production function shows that per-capita GDP is strictly proportional to productivity:$$
y_{t} / L=\kappa^{\alpha} A_{t} .
$$ 


\subsection{Innovation technology}

Our theory of productivity growth takes into account that every sector in every economy has access to a global stock of technological knowledge. As in Howitt and Mayer-Foulkes (2005), we assume that local firms can access the frontier technology on their own, although at a cost which increases with the distance between the local and the frontier productivities. In addition, we introduce the possibility for local entrepreneurs to turn to a foreign investor who has mastered the frontier technology in order to access that technology at a potentially lower cost. Both accumulated savings and the country's distance to the technological frontier will affect the feasibility or the attractiveness of this latter type of arrangement relative to the former innovation technology.

Suppose accordingly that at any point in time in each sector there is one old person who can act as the local entrepreneur, and who has the potential to displace the incumbent by innovating and thus being able to produce a superior intermediate product in that sector. Specifically, a successful innovator in any sector $i$ can produce with a productivity parameter $\bar{A}_{t}$ that embodies the current global frontier technology. Suppose that the frontier technology $\bar{A}_{t}$ grows at the constant rate $g$, which depends on the pace of innovation in the richest countries. (For our purposes we can take $g$ as given.)

There are three inputs to the innovation process: first, a costless input from a local entrepreneur; second, an unobservable effort $e$ on the part of the bank to monitor the entrepreneur and make sure she does not run away with the money; and third, an investment $f$ that is needed to transfer the frontier technology. To innovate, the entrepreneur must undertake a project, either with a foreign investor or without.

\subsubsection{Innovation with a foreign investor}

If the entrepreneur undertakes a project with a foreign investor, then the probability $\mu$ that the project will succeed (i.e. that the bank and the foreign investor will receive a positive return) is:

$$
\mu=\left\{\begin{array}{c}
\bar{\mu} \text { if } f \geq f_{t}^{\min } \text { and } e=1 \\
\underline{\mu} \text { if } f \geq f_{t}^{\min } \text { and } e=0 \\
0 \text { otherwise }
\end{array}\right.
$$

where:

$$
\bar{\mu}>\underline{\mu}=q \bar{\mu}>0,
$$

with $\bar{\mu}$ being the actual probability of innovation and $q<1$ being the probability that the entrepreneur will not be able to hide her cash returns in the absence of monitoring by the bank, and where:

$$
f_{t}^{\min }=\phi \bar{A}_{t}
$$

denotes the minimum investment that must be made by the foreign investor at date $t$ for that sector to innovate with positive probability.

The cost of the investment $f$ is just $f$ itself. The cost $C_{t}$ of monitoring by the bank in a given sector is proportional to the frontier level of productivity:

$$
C_{t}=e \cdot(c / u) \cdot \bar{A}_{t},
$$


where $c$ is a random variable, independently and identically distributed across sectors, uniformly between zero and one, and $u$ is a (positive) parameter that measures the efficiency of financial intermediation.

We also assume that the bank's monitoring effort cannot be observed by anyone else. This means that the bank will choose to shirk on monitoring a project, setting $e=0$, unless it has enough at stake in the success of the project. As we show below, this implies that it may have to cofinance the foreign investment $f$, or equivalently to post collateral which accrues to the foreign investor in the event the project does not succeed.

\subsubsection{Innovation without a foreign investor}

If the entrepreneur undertakes a project without a foreign investor, then she does not need any monitoring effort, since she is not going to run away from herself. In this case the probability of success is just the probability of innovation, $\bar{\mu}$. Assume that the cost of the investment $f$, which must be undertaken by the entrepreneur herself, depends inversely upon how familiar she is with frontier technology last period, which in turn we assume depends positively on how close the country was to the frontier last period. That is, the cost is:

$$
\left(\phi / \psi\left(a_{t-1}\right)\right) \bar{A}_{t}
$$

where $a_{t-1}$ measures the country's distance to the frontier:

$$
a_{t-1} \equiv A_{t-1} / \bar{A}_{t-1}
$$

and $\psi$ is a continuous function with:

$$
\psi^{\prime}(a)>0, \quad \psi(0)=0 \text { and } \psi(1)=1 .
$$

\subsection{Equilibrium innovation}

Let $V_{t}$ denote the value of an innovation at date $t$. Since the entrepreneur is in her last period of life, under the simplifying assumption that in the event of no innovation next period control of the incumbent firm will fall randomly to someone of the next generation, the monopoly rents from a successful innovation will last for one period only, so we have:

$$
V_{t}=\theta \bar{A}_{t}
$$

We then make the following assumptions:

1. Innovation at rate $\bar{\mu}$ is always worth the innovation cost when undertaken with a foreign investor, even when the monitoring cost is at its maximal value $1 / u$ :

$$
\bar{\mu} \theta-\phi \geq 1 / u
$$

2. No innovation project is worth the innovation cost without the local bank's monitoring:

$$
\underline{\mu} \theta<\phi
$$


The equilibrium rate of innovation in the economy at date $t$ will equal the innovation probability $\bar{\mu}$ times the fraction of sectors $\lambda_{t}$ in which a project is undertaken. To determine $\lambda_{t}$, first note that a project undertaken without a foreign investor will yield a non-negative expected return to the entrepreneur $\left(\bar{\mu} \theta-\phi / \psi\left(a_{t-1}\right) \geq 0\right)$ if and only if the country is close enough to the frontier; that is, if and only if $a_{t-1} \geq \widehat{a}$, where $\widehat{a}$ is defined by: ${ }^{3}$

$$
\psi(\widehat{a})=\frac{\phi}{\bar{\mu} \theta} .
$$

Accordingly every entrepreneur will undertake a project when a country is closer than $\widehat{a}$ to the frontier, so:

$$
\lambda_{t}=1 \quad \text { if } a \geq \widehat{a} .
$$

In a country further from the frontier, with $a<\widehat{a}$, the only projects that will be undertaken are those that involve a foreign investor. The fraction $\lambda_{t}$ will be the fraction of sectors in which a project could possibly yield non-negative expected surpluses to the bank, the entrepreneur and the foreign investor, while at the same time giving the bank an incentive to monitor. For purposes of determining $\lambda_{t}$ we assume with no loss of generality that all the expected surplus accrues to the bank, with the entrepreneur receiving nothing and the foreign investor receiving precisely the opportunity cost of that part of his investment $f$ that is not financed by the bank.

The expected surplus to the bank on a given project with a foreign investor equals

$$
(S-c / u) \bar{A}_{t}
$$

where the "primary surplus" $S$ is defined as:

$$
S=\bar{\mu} \theta-\phi
$$

Condition (1) above guarantees that the expected surplus is always positive, and hence that all investors can receive a non-negative expected surplus. Hence $\lambda_{t}$ will be the fraction of projects on which the bank can be given an incentive to monitor.

Whether or not the bank has an incentive to monitor a particular project will depend on how much of the initial cost $\phi$ it has financed. Consider a project in which the bank has financed the amount $y A_{t}$, and the foreign investor has put up the remaining $(\phi-y) A_{t}$. Let $x \bar{A}_{t}$ (resp. $(\theta-x) \bar{A}_{t}$ ) denote the foreign investor's (resp. the bank's) reward in the event of a successful innovation in the corresponding sector. The bank's incentive-compatibility constraint is:

$$
(\bar{\mu}-\underline{\mu})(\theta-x) \geq c / u
$$

That is, the increased expected payoff cannot be less than the monitoring cost. This can be turned into a constraint on the amount of finance $y \bar{A}_{t}$ by taking into account our assumption that the expected surplus of the foreign investor $[\bar{\mu} x-(\phi-y)] \bar{A}_{t}$ equals zero:

$$
y \geq-S+\Delta \cdot(c / u)
$$

\footnotetext{
${ }^{3}$ It follows (1) and the conditions imposed above on $\psi$ that $\widehat{a}$ lies strictly between zero and one.
} 
where

$$
\Delta=\frac{\bar{\mu}}{\bar{\mu}-\underline{\mu}}>1
$$

The right-hand side of (2) shows the minimum cofinancing (normalized by $\bar{A}_{t}$ ) that needs to be made by the local bank in order for a project to be undertaken with a foreign investor. The maximum cofinancing she can provide in total across all sectors is equal to:

$$
\sigma \omega A_{t-1}
$$

where $\omega$ is the productivity-adjusted wage rate derived above. A higher saving rate $\sigma$ will thus facilitate innovation by allowing the bank to cofinance more projects. If total finance is a constraint, then the bank will finance all projects up to some threshold value of $c$ (since lower monitoring costs yield a higher expected surplus to the bank and use up less financing according to (2)). That threshold will be the fraction $\lambda_{t}$ of projects that are undertaken, given that $c$ is uniformly distributed over the unit interval.

In sectors where the effort variable $c$ is less than

$$
\underline{c}=u S / \Delta
$$

no cofinancing is required by the incentive-compatibility constraint (2); all such projects will be financed. Accordingly, $\lambda_{t}$ is determined by the "finance constraint" :

$$
\int_{\underline{c}}^{\lambda_{t}}\left(-S+\Delta \frac{c}{u}\right) d c=\frac{\sigma \omega a_{t-1}}{1+g},
$$

in which the two sides represent respectively the amounts of finance required and available, both normalized by $\bar{A}_{t}$. Solving the integral and making use of the above definition of $\underline{c}$ yields:

$$
\lambda_{t}=\underline{c}+k \sqrt{\underline{c} \sigma a_{t-1}} \quad \text { if } a<\widehat{a} .
$$

where $k$ is a constant. ${ }^{5}$.

According to (A1) and (A2), when a country is close to the frontier saving has no effect on innovation because local finance is not needed to attract foreign investment, whereas when the country is far enough from the frontier the saving rate $\sigma$ increases innovation by increasing the number of projects for which local finance can attract foreign investment.

\subsection{Equilibrium dynamics and theoretical predictions}

Productivity in any sector $i$ that undertakes a project at date $t$ increases randomly according to:

$$
A_{i t}=\left\{\begin{array}{c}
\bar{A}_{t} \text { with probability } \bar{\mu} \\
A_{i t-1} \text { with probability } 1-\bar{\mu}
\end{array},\right.
$$

\footnotetext{
${ }^{4}$ For simplicity we assume that $\lambda_{t} \leq 1$. Relaxing this assumption would strengthen our result because it would add another reason why increased saving would have no effect on a country close enough to the frontier (in this case close enough that the solution to the integral equation is $\lambda_{t}>1$ ); that is, when a country becomes rich enough then its savings will already enough to attract foreign investment on all possible profitable projects.

${ }^{5} k=\sqrt{2 \omega} / \sqrt{S(1+g)}$
} 
whereas sectors that do not undertake a project do not grow. Integrating over $i$, we find that aggregate productivity evolves according to:

$$
A_{t}=\lambda_{t} \bar{\mu} \bar{A}_{t}+\left(1-\lambda_{t} \bar{\mu}\right) A_{t-1} .
$$

Dividing both sides by $\bar{A}_{t}$, we obtain a simple dynamic equation in $a_{t}\left(=A_{t} / \bar{A}_{t}\right)$, namely:

$$
a_{t}=\lambda_{t} \bar{\mu}+\frac{1-\lambda_{t} \bar{\mu}}{1+g} a_{t-1}
$$

This "distance" equation describes the current dynamic evolution of the country's distance to the world technological frontier, given the current fraction of sectors $\lambda_{t}$ that have undertaken an investment project and hence are capable of innovating with positive probability.

Our primary interest is in the equilibrium growth rate $g_{t}$, defined by:

$$
1+g_{t}=\frac{A_{t}}{A_{t-1}}=\left(\frac{a_{t}}{a_{t-1}}\right)(1+g)
$$

or, using (Dist):

$$
g_{t}=\left(\frac{1+g}{a_{t-1}}-1\right) \lambda_{t} \bar{\mu}
$$

We are also interested in the relationship between the saving rate and the total amount of FDI, namely

$$
f \lambda_{t}
$$

Proposition 1 (i) The effects of a higher saving rate $\sigma$ on total FDI and on growth are both strictly positive when $a_{t-1}<\widehat{a}$ and zero otherwise; (ii) for $a_{t-1}<\widehat{a}$, the positive effect of $\sigma$ on growth increases with $u$ and decreases with $a_{t-1}$.

Proof. Part (i) follows immediately from results (A1) and (A2). To show part (ii) note that

$$
g_{t}=\left(\frac{1+g}{a_{t-1}}-1\right)\left(\underline{c}+k \sqrt{\underline{c} \sigma a_{t-1}}\right) \bar{\mu}
$$

Then

$$
\frac{\partial g_{t}}{\partial \sigma}=\left(\frac{1+g}{a_{t=1}}-1\right) \frac{\bar{\mu} k \sqrt{\underline{\underline{c}} a_{t-1}}}{2 \sqrt{\sigma}}
$$

which is increasing in $u$ (since $\underline{c}$ is proportional to $u$ ) and decreasing in $a_{t-1}$.

Part two of this proposition is fairly intuitive. A more efficient financial system (larger $u$ ) is going to make better use of any increased saving. On the other hand, even though being closer to the frontier increases the normalized productivity $a_{t-1}$ on which saving is based, diminishing returns to saving (because $c$ increases on the margin) means that this effect on the economy-wide frequency of innovations $\lambda_{t} \bar{\mu}$ is offset by the reduced average size of innovations $\left(\frac{1+g}{a_{t-1}}-1\right)$, which falls more than in proportion to $a_{t-1}$.

Thus: in a country that is not too close to the frontier, growth and FDI respond positively to an increase in the domestic saving rate, whereas in a country close enough to the frontier growth is not significantly affected by saving; moreover, the positive effect of savings on growth is enhanced by a higher degree of financial development. It is these predictions that we shall explore in the next section. 


\section{Anecdotal evidence from East-Asia}

Before presenting formal econometric evidence in support of the model's predictions and mechanisms in the next section, it is illustrative to study the process of technology upgrading with the help of some case studies drawn from East-Asian experience. ${ }^{6}$

\section{Japan in the post WWI period}

Japan during the post WWI period illustrates (i) the importance of foreign involvement for catching up with the technology frontier, (ii) the relevance of domestic savings for providing liquidity to the banking sector and (ii) how this financial liquidity enables transactions with foreign technology suppliers.

Most of the new technology implemented in Japanese manufacturing during the 1920s was of foreign origin. In many sectors, the usual practise was to buy the technology from a domestic supplier and then to try to reverse engineer it. Technology transfer also took the form of foreign direct investment. Most of the FDI was in capital and technology intensive industries such as machinery, electrical goods, steel and iron goods, and rubber goods. In these cases, a foreign firm would either set up a fully owned subsidiary or it would enter in a joint partnership with an existing Japanese firm. These joint partnerships provided the Japanese firms with the technology and capital they lacked to make a further expansion. ${ }^{7}$

By 1931, 50.5 percent of foreign direct investment was already in the form of joint enterprises. $^{8}$ Japan in the 1920 s lacked a broad stock market for publicly issued securities. Individual savings were mobilized in the form of bank deposits. Big Japanese manufacturing firms overcame the lack of financial markets by forming conglomerates that also controlled big banks and trust companies. This provided ample liquidity to firms in metallurgy, equipment, chemicals, etc., that required large amounts of capital. In particular, this organizational arrangement allowed the firms that required more capital to access the individual savings deposited in the banks. As it turned out, heavy industry sectors were at the center of the financial conglomerates and also were the ones that received foreign technology transfer through joint partnerships (Islam, 1960).

\section{Korea in the 1960s}

When Park took office in 1962, Korea was emerging from the 1958-62 recession period where inflation had been high. In an effort to reduce high inflation the government designed the 1965 interest rate reform on the basis of the successful experience of Taiwan's high

\footnotetext{
${ }^{6}$ Of course, the mechanisms emphasized by our model hold more generally, as shown for example by Nicholas (1974). This author conducted a study that covered 27 small- and medium-sized manufacturing enterprises in Ghana and Senegal, two countries that are far from the technological frontier. He interviewed the managers in each firm and asked them about the process of technology upgrading. In most cases, successful upgrading involved the help of foreign technicians that trained workers and guided local entrepreneurs in acquiring machines. Though not covered by this study, the help of foreign entreprenurs and investors is surely even more relevant for upgrading technology in large enterprises.

7 "As a matter of fact, the resort to foreign partnerships was most of the time precisely for technological innovation in fields in which the Japanese did not have the adequate knowledge or resources." Islam (1960)

${ }^{8}$ This surge of joint partnerships with foreign firms started long before 1932 when the new military regime imposed a minimum Japanese share in foreign corporations operating in Japan.
} 
interest policy during 1950-58. The Monetary Board of Korea, a committee within the central bank, announced that the ceiling rate on saving deposits was being raised from 15 percent per annum to 30 percent (Brown [1973], Kuznets [1977] and Kim [1991]). During the 1960-1965 the inflation rate was 19 percent. As a result, the real return on savings was negative before the interest rate reform. In particular, in 1964 the real annual interest rate on savings accounts was -17 percent (Brown, 1973). After the 1965 reform, the real interest rate on long term bank deposits was 11.2 percent in 1965 .

The interest rate reform resulted in a rapid increase in bank savings deposits beginning in the fourth quarter of 1965. The constant-price value of savings deposits rose nearly 50 percent in the final three months of 1965. The increase in interest rates raised savings both because it increased the nominal rate and because the decline in demand reduced the inflation rate. Hence the effect of the reform was quite persistent and the constant-price value of savings deposits rose by 110 percent in 1966, and by 80 percent and 100 percent in 1967 and 1968, respectively. ${ }^{9}$

During the period 1962-66, local authorities made the first noticeable efforts to attract foreign direct investment. These first took the form of new laws allowing for temporary tax holidays, or for duty-free import of machinery and raw materials approved as investment requirements, or allowing for the remittance of principals and profits and protected property against expropriation (Kuznets [1977], Kim and Roemer [1981]). In addition, various measures aimed at promoting exports made it more attractive for foreign investors to transfer technology (Westphal, 1978). And in those, local credit features prominently. First, credit subsidies provided low interest loans to exporters with letters of credit from foreign importers. These credit lines provided liquidity to producers of goods that were sufficiently competitive to be exported. This helped them provide collateral to foreign investors that helped them upgrade their technology. Second, the Korean Exchange Bank also provided suppliers' credit. Foreign suppliers of plant, equipment and raw materials to Korean exporters provided the largest source of funds for export. Interestingly, the credits and loans provided by these foreign suppliers were secured by the Korean Exchange Bank (Kuznets, 1977). These credit policies in turn could be sustained thanks to the large amount of private savings deposited in the government's Bank in response to the interest rate reform.

These reforms surely helped solve the moral hazard problem associated to the international transfer of technology since the flow of technology transferred to Korea increased substantially during the period 1962-73. One of the channels by which foreign technology transferred is foreign direct investment. In August 1962, the first case of a direct foreign private investment, a US-Korea joint-venture firm producing nylon filaments, was approved by the Government of the Republic of Korea. In the next decade, foreign direct investment flows increased very fast. In 1973, the number of projects approved reached 271 and the value of foreign private investment $\$ 262$ millions (Jo, 1980). A few facts indicate that FDI was an active channel by which foreign technology was transferred to the Korean economy. First, FDI was directed, disproportionately, to high-tech sectors such as chemicals, machinery and machine parts, and specially to electric and electronic machinery. Second, foreign-invested

\footnotetext{
${ }^{9}$ The post-1965 period was a period of rapid growth in Korea. Brown (1973), however, shows that the increase in real interest rates that followed the 1965 reform had a very strong and significant effect on the private saving rate in Korea after controling for the effect that private disposable income has on savings.
} 
firms tended to import much more than local firms. Third, joint-venture firms tended to import a substantial proportion of intermediate inputs from their foreign partner companies. Fourth, foreign-invested firms had twice as much machinery and equipment per worker than that of local firms and produce 80 percent more value added per worker. Finally, a larger share of the output produced in foreign-invested firms was exported.

FDI is not the only channel by which foreign technology is transferred. Another channel is technological licensing. Jo (1980) documents the ever-increasing trend in Korea's technological licensing agreements with foreign firms. Most of these were made with Japanese and US firms. In 1962 only 5 agreements were approved. In 1975, 93 new technology licensing agreements were approved, and the total royalty payments in that year amounted to almost $\$ 19$ millions. As with FDI, most of the licensing agreements were signed by firms in high-tech sectors such as electric and electronics, machinery and chemicals.

This increasing adoption of foreign technologies contributed to high and persistent growth. During the recession period of 1958-62 the Korean economy did not experience any growth in output per worker. ${ }^{10}$ During the period 1962-68 the average annual growth rate in output per worker was 6 percent, while during the period 1968-74 it was 6.3 percent. Restoring full capacity generated a significant part of the acceleration of growth during the 1962-68 period, but the continuous and increasing adoption of frontier technology helped maintain the impressive growth rates once full capacity was restored.

This view of the growth experience in Korea is not undisputed. Carroll, Overland and Weil (2000) have argued that growth in Korea started during the second half of the 50s, long before the interest rate reform and the increase in domestic private saving. Indeed, output per worker during the period 1953-58 grew at an average annual rate of 3.8 percent. This, however, was the result of a neoclassical catch-up process after the destruction of capital during the Korean War. During the war (1950-53), civilian casualties approximated one million, including those killed, wounded and missing (Bank of Korea, 1955). War damage to non-military capital and structures has been estimated at $\$ 3.1$ billion at the implicit exchange rate for 1953. The estimates of the Korean GDP in 1953 vary substantially. The estimate of the Bank of Korea implies that non-military assets war damage was equivalent to 86 percent of 1953 GNP. The estimate of Nathan Associates implies that the war damage on non-military assets was twice the GNP in 1953. According to an estimate made by the Ministry of Commerce and Industry, war damage to manufacturing facilities was equivalent to 42 to 44 percent of pre-war facilities (Hwang, 1971). It was not until 1960 that the post-war reconstruction was completed (Kim and Roemer, 1981). ${ }^{11}$

\section{Taiwan in the 1950s and 1960s}

Taiwan offers a very similar picture to Korea with just a few important differences with respect to the development of financial markets. Taiwan showed a remarkable saving rate at least since the early 50s. Despite very low income per capita levels (\$100 in 1950) and coming out of hyperinflation (annual percentage inflation rates of 3400, 305, 66 and 23 between 1949

\footnotetext{
${ }^{10}$ The following computations use the Penn World Tables.

${ }^{11}$ The post-war reconstruction of Korea was largely financed by the US and by the UN. During the period 1953-60, total assistance provided by the UN amounted to approximately $\$ 120$ million, and official IUS assistance reached over $\$ 1.7$ billion.
} 
and 1952), the saving rate in 1952 was as high as 9.2 percent. As in Korea in the early 1960s, the government promoted saving by pursuing a high interest rate policy. This interest rate policy also led to a reduction in inflation which induced a further increase in the real interest rate. The real interest rate averaged 17 percent between 1952 and 1958. In addition, private savings were indirectly promoted by the government through complementary policies such as a very low social security safety net, a limited availability of consumer credit, high down payments for housing and a variety of favorable tax policies (Chiu 1992, Myers 1984, and Stallings 1990). These policies resulted in an impressive increase in the saving rate, from 12 percent in 1962 to 22 percent in 1968 and 35 percent in 1973.

The Taiwanese financial system is dominated by the government-controlled local commercial banks and by the Central Bank which provide credit mostly to large firms. In addition, small businesses could obtain resources from the "curb market": "an unregulated, semi-legal credit market in which loan suppliers and lenders can transact freely at uncontrolled interest rates." (Wade, 1985).

Taiwan's link to international markets was restricted by the stringent capital controls that were in place until the 1980s. The exception to this rule was FDI. In the early 1970s, one fifth of manufacturing production came from fully or partially foreign-owned firms. FDI has been concentrated in a few advanced manufacturing sectors. For example, between 1952 and 1979, two thirds of FDI in Taiwan was concentrated in Electronics (48 percent) and Chemicals (15 percent). Foreign firms played a major role in the development of these industries and helped upgrade the technologies used in these industries for example by producing advanced synthetics (Clark, 1997).

One example of successful technology transfer is the case of the Singer Sewing Machine Company that revolutionized the local industry in Taiwan. Before Singer arrived in Taiwan in 1963, the sewing machine industry consisted of approximately 250 family-owned firms assembling sewing machines and providing parts for the assemblers. Taiwan Singer started production in 1964. It provided considerable technical assistance to its local suppliers, furnishing them with blueprints, providing training and technology transfer in production, quality control, factory management and in standardizing parts. These gave a tremendous impulse to the local producers, both to the suppliers that dealt directly with Singer and to the rest which were able to improve their technologies by interacting with Signer's direct suppliers. This resulted in a fifteen-fold increase in production between 1963 and 1973. Furthermore, while Taiwan Singer played a major direct role in the initial increase in production, domestic firms soon dominated both the domestic and export markets. After 1968, Taiwan Singer's share of Taiwanese production dropped to about 10 percent. The upgrading of Taiwanese technology to the world frontier occurred very quickly. The resources to finance the technological upgrading for the hundreds of small domestic firms came mostly from the curb market which was fed by-and-large by domestic private savings.

However, the lack of an efficient formal financial market in Taiwan has been a constraint for the acquisition of technologies that, because of the size of the necessary foreign investments, required larger amounts of collateral to enable the transfer. This was the case in the automobile industry. All the various projects that were attempted to upgrade the automobile industry did not pass the planning stage. Though the threat of foreign entry stimulated domestic producers to become more productive, these remained far from becoming internationally competitive. 


\section{Econometric evidence}

We now confront the implications of our model to econometric analysis. Causality in macro data is inherently hard to uncover, so the reader should interpret the correlations that follow as suggestive. The main point obtained is that the many correlations we examine in the data are consistent with the model, including the differential effects between rich and poor countries, and we are not aware of any alternative theory that would be consistent with all these correlations.

Our exploration is based on a cross-country panel over the period from 1960 to 2000. We use a sample of 118 countries, all those for which there exist data on per-worker GDP and on the saving rate. Data on income per worker comes from the Penn World Tables 6.1. For the saving rate we use both the series from the Penn world Tables and from the World Bank. These measures differ in that the former is measured in international prices while the latter is measured using domestic prices. Hsieh and Klenow (2005) show that, unlike the investment rate, the cross-country correlation of the saving rate with income per capita is about the same whether the saving rate is measured in domestic or international prices. Due to the larger data availability of the Penn World Table data we make this our primary saving rate measure but we prove the robustness of our results to using World Bank saving rate measures for some representative regressions. Table 1 contains descriptive statistics for the variables used in our analysis.

The main empirical implications of our model concern the differential effect of savings on growth for countries that are far from the technology frontier (i.e. $a<\widehat{a}$ ). To implement the test of this prediction, we classify countries each year in two groups depending on whether the log-income gap with the highest income per capita country is above or below the median gap (i.e. 1.8). That is, a country is poor if it has an income per capita below 16.5 percent the income per capita of the richest country and it is rich if it has an income per capita above this threshold.

\section{Econometric specification}

The specification used to investigate the relationship between savings and growth regression (4) - follows closely equation (3) in our model. In this specification, the dependent variable is the growth rate of income per worker between year $t$ and year $t+10$. We choose a difference of ten years because the mechanism embedded in our model is more relevant in the medium term than in the very short term.

$$
\ln \left(y_{i t+10} / y_{i t}\right) / 10=\alpha_{i}+\rho t+\beta \ln y_{i t}+\gamma s_{i t, t-4}+\epsilon_{i t} .
$$

The independent variable of interest is the average saving rate in the five-year period between $t-4$ and $t$ denoted by $s_{i t, t-4}$. The saving rate variable, which includes public as well as private saving, is defined as one minus the ratio of private consumption to GDP minus the ratio of government purchases to GDP. Using a five-year average of savings instead of the annual saving rate at $t$ serves three purposes. First, it reduces the measurement error present in annual data. Second, it better captures the notion that collateral is a stock not a flow. We will explore below the robustness of the results to allowing for longer periods over which savings are accumulated. Third, by using lagged measures of the independent variable 
we reduce the possibility of reverse causality. Of course, the ideal empirical counterpart to the saving rate in the model would be some measure of collaretabizable domestic assets. Unfortunately, this variable is unavailable for a panel such as ours and we have to use a noisy proxy such as the average saving rate for the last 5 years.

In our regressions, we follow the convergence literature (and equation (3)) and allow for the initial log-level of income per worker $\left(\ln y_{i t}\right)$ to have an effect on the subsequent growth rate. We also include a time trend and country fixed effects to control for trends and very persistent differences in productivity growth driven by factors not captured by our theory. Countries may differ, for example, in the degree of property right protection and this may affect the cross-country relation between lagged savings and growth. This relationship, however, is orthogonal to our model's mechanisms and we would like to filter it out from our analysis with the country fixed effects. Finally, in the robustness analysis, we verify that our findings persist after including year fixed effects that capture global annual fluctuations in the variables.

Our empirical strategy consists in estimating regression (4) for three samples, the sample of all countries, the sample of poor countries and the sample of rich countries. Therefore, the speed of convergence and the time trends may in principle differ by income group.

Recent studies by Carroll and Weil (1994) and Attanasio, Picci and Scorcu (2000) have conducted Granger causality tests between growth and the saving rate in a panel of countries. Our specification differs from these studies in at least three respects. First, we are interested in exploring the medium term effect of savings on growth rather than the contemporaneous and short term relationship between these variables. Second, unlike these statistical explorations, ours is model-guided investigation, and our model indicates that when estimating the relationship between lagged savings and growth we should control for initial productivity. This control is missing from the specifications used to conduct Granger causality tests. Third, our identification strategy focuses on the differential effect of lagged savings on growth in poor vs. rich countries and by estimating separately our specification in these samples we are able to uncover some of the heterogeneity that exists in the relationship between lagged savings and growth across countries.

Since the periods used to compute the growth rate of income per capita and the saving rates overlap, the error terms may be autocorrelated. We use the Newey-West method to obtain correct standard errors for the estimated coefficients. To obtain some guidance on the length of the truncation in the computation of the Newey-West standard errors, we apply the rule of thumb proposed by Stock and Watson (2002) which suggests that we should truncate after two lags. The statistical significance of our results, however, is robust to truncating after much longer lags. ${ }^{12}$

\section{Lagged savings and productivity growth}

The first three columns in Table 2 report the estimates from (4) in our three samples. Column 1 covers all the country-years; column 2 restricts the sample to country-year pairs above the median income gap, that is, poor countries, while column 3 restricts the sample to rich countries. In the full sample we observe the standard result of convergence in income per worker after introducing country fixed effects. As predicted by our model, we find a

\footnotetext{
${ }^{12}$ We have experimented with up to 10 lags without any change in the significance of our findings.
} 
significant positive association between savings and productivity growth in the ten years going forward.

A more interesting prediction of our model is that the effect of savings on growth should be larger for countries far from the technology frontier than for countries close to the frontier. This prediction is borne by the data. Comparing the coefficients of savings in columns 2 and 3 we can observe how for poor countries the coefficient of savings in the growth regression is 3.9 percent while for rich countries is less than half this magnitude. The association between lagged average savings and productivity growth for poor countries is very significant while for rich countries the t-statistic is just $1.67 .{ }^{13}$ The difference in the coefficient of savings between the two samples is statistically significant at the 10 percent level. Note also that the estimated effect of lagged savings on growth is of quantitative importance. An increase in the average saving rate between $t-4$ and $t$ of 10 percentage points is associated with an increase in the average growth rate in output per worker of four tenths of one percentage point over the next ten years.

This differential effect between rich and poor countries is the opposite of what we would have expected to have resulted if measurement error was a major issue, given that the quality of data in the Penn World Tables is generally lower for poor countries than rich. In particular, higher measurement error in saving rates probably caused more attenuation of its estimated effect in poor countries than rich.

The remaining six columns in Table 2 check the robustness of these results. Columns 4 through 6 report the estimates of the following regression where the time trends are replaced by year fixed effects.

$$
\ln \left(y_{i t+10} / y_{i t}\right) / 10=\alpha_{i}+\rho_{t}+\beta \ln y_{i t}+\gamma s_{i t, t-4}+\epsilon_{i t} .
$$

Including year fixed effect does not affect very much the estimated association between lagged average savings and subsequent productivity growth. The coefficients of savings decline a little both for rich and poor countries but the one for poor countries remains very significant and the gap between the two persists after the inclusion of the time dummies.

Columns 7 through 9 of Table 2 include as control the degree of trade openness in the economy at year $t$ measured by the sum of the export and the import shares in GDP. This variable has been identified by several authors (including Frankel and Romer, 1999) as an important determinant of growth. In line with their results, we find that it is significantly associated with subsequent growth. However, its inclusion does not affect the relationship between savings and growth. In particular, lagged average savings is strongly associated with productivity growth in the whole sample and in the sample of poor countries while it is not significantly associated with growth in the sample of rich countries. Note however, that the difference in the effect of lagged savings on productivity growth between poor and rich countries in columns 4 through 9 is not statistically significant. As we show next, this differential effect of savings becomes very significant when looking at saving rates measured in domestic prices and when decomposing the sources of growth.

\section{Private vs. public savings}

\footnotetext{
${ }^{13}$ When using 10 lags to compute the Newey-West standard errors, the t-stat for the coefficient of lagged savings in poor countries is 2.2 while in rich countries it is 0.98 .
} 
In our model, savings matter only because of their role as collateral when undertaking technology adoption projects with a foreign investor. If public savings can be used as collateral by private agents, then the model predicts that the effect of private and public savings should have a symmetric effect on growth. However, if public savings cannot be used as collateral for private projects, then the mechanisms presented in the model imply that private savings should have a stronger effect on growth than public savings. Further, to the extent that government savings constitute a transfer of resources away from the private economy and this may reduce private savings, our model may predict a negative effect of public savings in countries far from the technology frontier but no effect in countries more familiar with the frontier.

Next, we explore whether the positive association that we have found between lagged savings and productivity growth operates through private or public savings. To do that, we use World Bank data on savings that divides these between private and public. These data also allow us to check the robustness of the results presented in Table 2 to measuring the saving rate in domestic rather than in international prices.

The first three columns in Table 3 reestimate regression (4) with the World Bank savings measures. The basic message from this exercise is that the differential effect of savings on growth for poor countries is robust to measuring the saving rate using domestic or international prices. Indeed, when using the World Bank saving rate measure we find that the effect of lagged savings on growth for poor countries is larger than when using saving rates from the Penn World Tables. For rich countries, instead, the estimated effect of lagged savings on growth is smaller when using the World Bank saving measure. Hence, when using saving rate computed with domestic prices to estimate regression (4), the differential effect of savings on growth for poor vs. rich countries increases.

Columns 4 through 6 reestimate regression (4) for the subsample of countries for which we have the decomposition of savings into private and public. Though the effect of savings on growth declines a little bit, its differential effect on the growth rate of poor countries also holds in this subsample.

Columns 7 through 9 estimate regression (6), where we allow for different coefficients on the growth effects of average lagged private saving rate over GDP $\left(\operatorname{spriv}_{i t, t-4}^{W B}\right)$ and average lagged public saving rate over GDP $\left(s p u b_{i t, t-4}^{W B}\right)$.

$$
\ln \left(y_{i t+10} / y_{i t}\right) / 10=\alpha_{i}+\rho t+\beta \ln y_{i t}+\gamma_{1} \operatorname{spriv}_{i t, t-4}^{W B}+\gamma_{2} s p u b_{i t, t-4}^{W B}+\epsilon_{i t} .
$$

The main finding from this exercise is that the differential effect of savings on growth for countries that are far from the frontier is completely driven by private rather than public savings. A ten percentage points increase in the average private saving rate of poor countries between $t-4$ and $t$ is associated with more than a half a percent increase in the average productivity growth rate during the following decade. In contrast, the point estimate of the effect of public savings on growth is negative but insignificant.

\section{Capital accumulation vs. TFP growth}

Productivity growth can result from TFP growth or from capital accumulation. In particular, if the aggregate production function takes the standard Cobb-Douglas form we can 
decompose the productivity growth measure over a ten year period as follows

$$
\ln \left(y_{i t+10} / y_{i t}\right) / 10=\ln \left(T F P_{i t+10} / T F P_{i t}\right) / 10+\alpha * \ln \left(k_{i t+10} / k_{i t}\right) / 10,
$$

where $k$ denotes capital per worker.

In our model, savings has a larger growth effect for poor than for rich countries because it allows them to build the collateral necessary to induce foreign investors to transfer frontier technology. Therefore, our model predicts that the differential growth effect of lagged savings in poor countries operates through TFP growth. This implication is in contrast with most existing models of savings and growth (e.g. Solow, 1956, Bernanke and Gertler, 1989) which predict that the growth effects of savings operate through capital accumulation.

To explore which channel is driving the relationship between savings and productivity growth, we build measures of the growth in capital per worker over ten year intervals $(t$, $t+10)$ using the same procedure as Hall and Jones (1999) to build aggregate capital stocks and the Penn World Tables to obtain information on the number of workers. Then we compute TFP growth over a ten year interval by assuming a capital share of one third and sustracting one third times the growth rate of capital per worker from the growth rate of GDP per worker.

We run the following two regressions in each of our three samples:

$$
\begin{gathered}
\ln \left(k_{i t+10} / k_{i t}\right) / 10=\alpha_{i}+\rho t+\beta \ln y_{i t}+\gamma s_{i t, t-4}+\epsilon_{i t} . \\
\ln \left(T F P_{i t+10} / T F P_{i t}\right) / 10=\alpha_{i}+\rho t+\beta \ln y_{i t}+\gamma s_{i t, t-4}+\epsilon_{i t} .
\end{gathered}
$$

Table 4 a contains the estimates from this exercise. Columns 4 through 6 correspond to regression (8) while columns 7 through 9 correspond to regression (9). The main finding from this exercise is that the positive association between lagged savings and growth observed in the overall sample and in the sample of poor countries is entirely driven by the association between lagged savings and TFP growth. For the entire sample, an increase in the average savings rate between $t-4$ and $t$ by 10 percentage points is associated with an increase in the average TFP growth rate between $t$ and $t+10$ by four tenths of one percentage point. In poor countries, a similar increase in the saving rate is associated to an increase in TFP over the subsequent ten years by half of a percentage point. In contrast to this, lagged savings does not have any significant effect on TFP growth in rich countries. Further, the difference in the effect of lagged savings on TFP growth between poor and rich country, in addition to being large - 3.7 percentage points- is statistically significant at the 1 per thousand significance level.

Columns 4 through 6 in Table 4a show that lagged savings is insignificantly associated to the growth in capital per worker between $t$ and $t+10$. This is the case in the whole sample, in the sample of poor countries and in the sample of rich countries. Further, the difference in the point estimates of lagged savings on growth in capital per capita between poor and rich countries is statistically insignificant.

Columns 4 through 9 in Table 4b report the estimates of regressions (8) and (9) but now we use the World Bank saving rate measure that uses domestic rather than international prices to measure savings and income. All the findings from Table 4a hold a fortiori when 
using the World Bank saving rate measures. In particular, an increase in the average saving rate between $t-4$ and $t$ by 10 percentage points is associated to an increase in the average TFP growth rate between $t$ and $t+10$ of almost seven tenths of one percentage point in poor countries while it has no effect on rich countries.

Before moving forward with our exploration it is convenient to make a remark about what the Solow residual measures. Since we have not adjusted the residual for human capital accumulation, it is going to be captured by our measure of TFP growth. However, we know since the work of Islam (1995) and others that schooling does not have a significant effect on growth in panel exercises such ours. Therefore, controlling for human capital accumulation would not change our finding that the association between lagged savings and growth operates through TFP rather than through factor accumulation. ${ }^{14}$

\section{Stock vs. Flow}

One simple way to improve our measure of the collateral in the economy is to increase the length of the interval over which we compute the average saving rate. Next, we consider how the estimates of the effect of lagged savings on growth change when we measured lagged savings by the average saving rate between years $t-9$ and $t$ rather than the average saving rate between $t-4$ and $t .^{15}$

Table 5 compares the estimates of lagged savings on growth when using 5 and 10 year averages. The main conclusion from this exercise is that extending the period over which we compute average savings does not affect the effect of savings on growth. This insensitivity of the estimated effect of average savings on growth to including lagged savings from the period $(t-9, t-5)$ may provide some support for the role of savings as collateral since one would think that savings at different lags have a similar effect on current collateral.

\section{Reverse causality}

A strand of the literature on growth and savings has emphasized that the causality does not run from savings to growth but from growth to savings. Most prominently, Carroll, Overland and Weil (2000) have argued that if consumers have internal habit, in response to an increase in their income prospects they will tend to save more to avoid the negative effects of a higher habit. This mechanism could, in principle, be consistent with our findings that lagged savings is positively associated to future productivity growth and to future TFP growth.

Of course, it is not obvious why this would happen more in poor than in rich countries as we have found in our analysis so far. Further, one would expect that the response to future growth prospect would be larger the more immediate are the realizations of growth. That would imply that we should observe a lower coefficient of savings on growth when looking

\footnotetext{
${ }^{14}$ In addition, recent work by Comin, Hobijn and Rovito [2006] shows that direct technology measures are highly correlated to TFP.

${ }^{15}$ The exclusion of the initial level of physical capital from this measure should not be a significant concern since after 10 years most of the initial capital stock will be depreciated. In particular, with a reasonable 10 percent depreciation rate, only one third of the available capital at year $t-9$ will remain at year $t$.
} 
at savings between $t-4$ and $t$ than when looking at more distant savings. That is not what we have found in Table $5 .{ }^{16}$

The reverse causality argument, however, may still be consistent with the insensitivity to the lag of savings of the coefficient of savings on growth if growth is very persistent. If this was the case, future growth would be highly correlated to current growth which would trigger very lagged savings. However, we know at least since Easterly, Kremer, Pritchett and Summers (1993) that average growth over decades presents very low autocorrelation. We also reach a similar conclusion when estimating the effect of productivity growth between $t-9$ and $t$ on productivity growth between $t$ and $t+10$ after controlling for log-productivity at $t$ and including the country fixed effects. ${ }^{17}$

Finally, one way to evaluate the power of the reverse causality explanation is the following. Let's take an off-the-shelf model where the causality runs from future growth to lagged savings, let's simulate it and let's run our regressions on the simulated data. Is the estimated relationship between savings and growth similar to the one we estimate in the data?

A positive answer to this question does not imply that reverse causality is driving the results presented so far because in the exercise we are posing a particular model that contains habit. However, a negative answer will make hard to reconcile the evidence with the reverse causation argument.

We consider two models for this calibration exercise. First, we simulate a standard real business cycle model with standard CRRA preferences separable in consumption and leisure. Then we simulate a model with internal habit for consumption with exogenous labor supply and exogenous productivity shocks. This habit model is quite similar to the model presented by Carroll, Overland and Weil (2000) and it is described in more detail in the Appendix.

Table 6 reports the results from various calibrations of these models. Columns 2 through 6 describe the model and the values used for the most relevant parameters. The Appendix contains the values used for the calibration for the other parameters. For each of these calibrations, we simulate 1000 50-year series and then for each simulated series we estimate regressions (4) and (9). Column 7 contains the average estimate of the effects of lagged savings on subsequent productivity growth and the 95 percent confidence interval for this average estimate. Column 8 contains the average estimate of the effects of lagged savings on subsequent TFP growth and the 95 percent confidence interval for this average estimate. In addition, we also compare the relative volatility of investment and output in the model with the data. In particular, we apply the Hodrick-Prescott filter to each simulated series and compute the ratio of the relative standard deviation of simulated investment over the standard deviation of simulated output. Column 9 report the average ratio for each calibration together with the 95 percent confidence interval of the average ratio.

Recall that the estimates from our regressions above are: (i) 3.9 and 4.6 percent for the estimated effect of lagged savings on productivity growth in poor countries depending on whether we measure the saving rate in international or domestic prices, and (ii) 5.2 or 6.7 percent for the effect of lagged savings on subsequent TFP growth in poor countries, also depending on whether we use international or domestic prices to measure the saving rate.

\footnotetext{
${ }^{16}$ If we look at the association between average savings between $t-9$ and $t-5$ and growth (between $t$ and $t+10)$ we observe that the coefficients are very similar to what we obtain when having as regressor average savings between $t-9$ and $t$ or average savings between $t-4$ and $t$.

${ }^{17}$ If we do not control for $\log$ productivity at $t$, the autocorrelation of productivity growth is even negative.
} 
Finally, it is well known that in developed economies investment is about 3 times as volatile as output, while in developing economies this ratio is about 4 (Gopinath and Aguiar, 2005).

The first two rows report the estimate of the effect of lagged savings on subsequent growth in the RBC model without habit. In this model we consider value for the annual autocorrelation of the TFP shocks equal to 0.8 (row 1) and 0.95 (row 2). As is well known, the simulations from this type of models are consistent with the relative volatility of investment and output observed in the data. However, we find that, irrespective of the calibration and whether we look at the growth of productivity or of TFP, in this type of model lagged savings is uncorrelated to subsequent growth.

Following the hypothesis of Carroll, Overland and Weil (2000), we simulate a model with strong internal habit. In particular, a habit persistence parameter of 0.8 implies that if the consumer does not change her consumption level from the previous period she will just enjoy 20 percent of her total consumption. Introducing internal habit tends to increase the consumer savings rate in response to expectations of higher income in the future. This, however, does not have much impact on the estimated correlation between lagged savings and subsequent growth once we control for the log-level of labor productivity at $t$. In rows 3 and 4 we observe how the average estimate of this conditional correlation in the data simulated from the habit model is negative when the dependent variable is the growth rate of labor productivity and very small average estimates when the dependent variable is the growth rate of TFP. In particular, for this latter case, the average estimate is less than one tenth the coefficient estimated for the sample of poor countries (row 3). Further, row 4 illustrates one problem that sometimes arises in the model with habit. Namely, that volatility of investment (relative to output) is too small. In this particular specification this results from the combination of habit and a high auto-correlation of the TFP shock. ${ }^{18}$

We next try to correct both of these problems by increasing the capital share to 0.7 , a value often rationalized with a broad interpretation of the concept of capital (e.g. Mankiw, Romer and Weil, 1992). A higher capital share increases the return to current investment and consumers save more in response to a productivity shock. This tends to increase the partial correlation between current savings and subsequent growth. However, it also reduces the volatility of investment relative to output. In our parametrization in row 5 , this relative volatility is less than 1.8. Even in this case, the average estimate of the effect of lagged savings on subsequent productivity growth is still negative (though very small). For TFP growth, this effect is about 3 percent while in the data the estimated effect ranges from 5.2 to 6.7 percent. Hence, it does not seem that the reverse causality of future growth on lagged savings predicted by habit models is sufficient to rationalize the large observed correlation between these two variables in the data. Row 6 tries to increase the relative volatility of investment by reducing the auto-correlation of the TFP shocks to 0.5. This increases slightly the relative volatility of investment but reduces to 2 percent the estimated effect of savings on TFP growth.

The last three rows of Table 6 explore the effect of increasing the habit persistence. This does not affect significantly any of the previous observations. Hence, we conclude that reverse

\footnotetext{
${ }^{18}$ This, and all the results discussed in this section are robust to varying the risk aversion coefficient. Typically, the estimated effect of lagged savings on subsequent growth declines with the coefficient of relative risk aversion.
} 
causality is not responsible for a significant part of the estimated effect of lagged savings on productivity or TFP growth in the countries that are far from the technology frontier.

\section{Omitted variable bias}

Both savings and productivity growth are endogenous variables. Therefore it is not possible for us to rule out the possibility that the observed relationship between lagged savings and productivity growth is not driven by a third variable that is omitted from our analysis. ${ }^{19}$ Though this is certainly possible, there are a few hurdles that the omitted variable must pass in order to drive our results.

First, the omitted variable cannot be very persistent or have a very persistent effect on growth because if this was the case its effect would be captured by the country fixed effect and would not account for the positive estimates of lagged savings on subsequent growth. Institutional and geographic variables are definitely rule out from the list of potential suspects.

Second, if the effect of the omitted variable on growth is very transitory, the exclusion of the variable from regression (4) is still an unlikely source of bias because in our regressions we control for the productivity level at the beginning of the period and this variable would capture very transitory growth effects from an omitted variable. Third, this restriction becomes slightly more stringent from the fact that the coefficient of savings on growth does not decline when using the average saving rate between $t-9$ and $t$ as regressor.

Finally, and most important, the omitted variable should be more correlated with savings in poor than in rich countries or alternatively affect differentially growth in poor vs. rich countries. Of course, it may be possible to find variables that satisfy these restrictions and therefore we cannot rule out the possibility that our estimates are driven by omitted variable bias. However, finding such a variable is not an easy task and our model provides an intuitive explanation of these findings.

\section{Savings, financial market development and growth}

So far, we have classified countries according to their per capita income and used this as a proxy to their distance to the technology frontier. ${ }^{20}$ However, it might be the case, that our classification based on income per capita differences captures factors other than technology differences. One possibility is that the income gap reflects cross-country differences in financial market development. Savings would then be more growth enhancing in low financially developed countries because would provide liquidity to the capital markets and enable the development of profitable projects that would not be undertaken otherwise. Financially developed countries may access more easily to international capital markets and, as a result, the number of profitable projects undertaken would not be so sensitive to domestic savings.

\footnotetext{
${ }^{19}$ An alternative approach consists on trying to instrument savings. Loayza, Schimdt and Serven (2000) use dependency ratios, urbanization rates, income inequality, volatility growth and growth as instruments. However, it is debatable whether these variables are exogenous.

${ }^{20}$ The literature on development accounting (Klenow and Rodriguez-Clare, 1997 and Hall and Jones, 1999) supports this exercise by finding that a very large fraction of cross-country differences in income per capita can be attributed to TFP. Further, Comin, Hobijn and Rovito (2006) show that TFP differences are highly correlated with cross-country differences in technology adoption.
} 
This story is a valid alternative to ours and suggests that there may exist an omitted variable in our analysis that operates through the classification of countries. This story however is significantly different from ours because it would predict that savings is a substitute for financial development while our model predicts that savings is complement to financial development. To test which of these two alternatives holds in the data, we conduct the following exercise. We classify countries by their financial market development measured, as it is usually done in this literature, by the private credit to GDP ratio. Then we run our growth regressions for productivity (4) and TFP growth (9) in the full sample, in the sample of countries with financial development below the median financial development in the year, and for the sample of countries with higher financial markets development than the median. To reduce noise in the savings measure we use the private savings measure. In particular, our regressor of interest is the average private saving rate between $t-4$ and $t$. Table 7 reports the estimates from this exercise.

Columns 1 through 3 and 7 through 9 in Table 7 show that the differential effect of lagged savings on the growth of poor vs. rich countries is robust to restricting the analysis to the subsample of countries for which we have data on private credit. The main finding from Table 7 is that the relative effect of savings on growth by income gap is very different from the relative effect by financial market development. When looking at productivity growth over the next 10 years, savings is more productive for countries with high than with low financial markets development. In particular, for the former the coefficient of average lagged private savings on productivity growth over the next 10 years is 0.03 , while for the former is -0.016. The difference between these two coefficients is statistical significant at the 5 percent level. This is illustrated by the last row where we report the p-value for the test of the null hypothesis that the effect of savings on growth is the same for high and low financially developed countries. For TFP growth (columns 11 and 12), we also find that private savings is associated with a larger growth effect for highly financially developed countries than for countries with low financial development. In particular, the coefficient of lagged average private saving rate for financially developed countries is 0.04 while for countries with low financial development it is -0.008 . The difference in the effects of savings on TFP growth for countries with high vs. low financial development is also statistically significant. Thus, as predicted by our model, financial development is complementary to domestic private savings. ${ }^{21}$

\subsection{Evidence on the mechanisms}

So far we have explored various predictions of our model using the reduced form relationship between savings and growth. To build a stronger body of evidence in support of the mechanisms emphasized by our model we explore the role of savings on foreign direct investment and on the imports of high-tech equipment. We also explore how including these variables in our baseline regressions affects the reduced form relationship between lagged savings and growth.

\footnotetext{
${ }^{21}$ Alfaro et al. (2004) also find that FDI and financial market development are complementary in a growth regression. In particular, they find that, in a cross-sectional growth regression at the country level, the interaction of FDI with financial market development enters positively.
} 


\section{FDI, savings and growth}

Foreign technology is transfer through a variety of channels that include foreign direct investment, technology licensing, imports of high-tech equipment, consulting/ advising services,etc. Next, we explore the relationship between the average saving rate and the average FDI-to-GDP ratio between $t$ and $t-2$ for those country-years where FDI is non-negative (equation (10)). The regression also includes a country specific constant and a time trend. As in our previous analysis, we estimate the relationship between savings and FDI for the three samples (full, poor and rich countries).

$$
F D I / G D P_{i t-2, t}=\alpha_{i}+\beta s_{i t-4 . t}+\gamma t+\epsilon_{i t}
$$

The first three columns in Table 8 contain the estimates from this regression. Two observations are worth making. First, savings are positively associated with FDI inflows. Second, the effect of savings on FDI is very similar for poor and for rich countries. Columns 4 through 9 of Table 8 also control for log of GDP per worker and for trade openness both in year $t-3$. Introducing these controls does not affect the positive relationship between savings and FDI.

A second question that we can address is whether FDI accounts for some of the estimated effect of savings on the growth of poor countries. To this end we estimate our growth regressions including the average FDI to GDP ratio between $t-2$ and $t$ as a control. In Table 9 we can observe how the FDI to GDP ratio between $t-2$ and $t$ is positively and significantly associated to both productivity growth and TFP growth in poor countries. In rich countries, the estimated partial correlation between FDI and either productivity growth or TFP growth is smaller than in poor countries (0.03 vs. 0.13 and 0.049 vs. 0.09 ) and statistically insignificant. This finding is consistent with our theory since it predicts that FDI in countries that are far from the frontier embodies a larger technology transfer than for countries that are close to the technological frontier.

FDI is one of the possible ways in which the foreign entrepreneur can help domestic producers catch up with the frontier. Therefore, since in our model savings matters for growth because it facilitates this technology transfer, our theory implies that controlling for FDI should reduce the estimated effect of savings on growth. This prediction is also borne by the data as is shown in Table 9. Controlling for FDI reduces the estimated effect of lagged savings on productivity growth of countries far from the frontier from 0.039 to 0.014. This estimate is statistically insignificant. Similarly, FDI reduced the coefficient of savings on TFP growth in poor countries by 1 percentage points (from 0.052 to 0.043 ).

Finally, note that, the decline in the growth effect of savings after controlling for FDI is substantially smaller in rich than in poor countries ( 0.008 vs. 0.025 for productivity growth and 0.002 vs. 0.009). All this seems to suggest that, as the model predicts, an important part of the differential effect of savings on growth for poor countries operates through the inflow of FDI which has a much higher return for poor than for rich countries.

\section{Equipment Imports, savings and growth}

In our model, the input provided by the foreign investor helps domestic producers to adopt better technologies. Many of these technologies are embodied in imported equipment. 
Hence, we can test the prediction that domestic savings will have a differential positive effect in the import of high-tech equipment for poor vs. rich countries. Caselli and Wilson (2004) have measured the technological sophistication of imports by the amount of R\&D that they embody. For each of nine categories of equipment, they measure the total R\&D expenses in the world and compute the share of total equipment R\&D that corresponds to each category. We follow their lead and come out with a measure of the equipment import share weighted by R\&D expenses. Formally, our measure of the equipment import share is defined as follows:

$$
e_{i m}=\sum_{j=1}^{9} \frac{R \& D_{j}}{\sum_{j=1}^{9} R \& D_{j}} i m_{j i t},
$$

where $i m_{j i t}$ is the share in GDP of the imports of equipment type $j$ in country $i$ at year $t$, and $R \& D_{j}$ denotes the total world $\mathrm{R} \& \mathrm{D}$ expenses in equipment type $j{ }^{22}$ The share of $\mathrm{R} \& \mathrm{D}$ expenses in a given equipment category in total $R \& D$ expenses is roughly constant since 1960. So we decide to use as weights the average share during the 1960-2000 period.

As with FDI, the first prediction of the model that we test is whether, the effect of savings on our measure of equipment imports is larger for poor than for rich countries. In this regression it is very natural to control for the imports share since countries with a higher import share will also tend to have a larger share of equipment imports in GDP. ${ }^{23}$

$$
\operatorname{eim}_{i t-2, t}=\alpha_{i}+\beta s_{i t-4 . t}+\rho i m_{i t-2, t}+\gamma t+\epsilon_{i t}
$$

Table 10 reports the estimates from regression (11). As predicted by the theory, savings in poor countries is positively associated with the R\&D weighted share of equipment imports in GDP. In particular, a ten percentage point increase in the average saving rate between $t-4$ and $t$ is associated with an increase in our R\&D weighted equipment imports share measure by 8.5 percentage points in countries that are far from the frontier. This effect is also statistically significant. Interestingly, the effect of savings on the equipment imports share for rich countries is not only smaller than for poor countries but negative. Columns 4 through 6 of Table 10 report the estimates from regression (11) after including the log of income per worker at $t-3$. Controlling for initial income does not affect the signs or magnitudes of the association between savings and equipment imports for any of the three samples.

Next, we reexamine the growth effects of savings after controlling for our measure of equipment imports. As discussed above, our theory predicts that the effect of savings on growth in countries far from the technological frontier operates in an important part through the import of more sophisticated equipment. To explore whether this may be the case in the data we include our measure of equipment imports weighted by R\&D over GDP in the control set for equation (4). A few interesting remarks are in place from the estimates reported in Table 11. First, as with FDI, the growth effect of equipment imports is larger for poor than for rich countries. In particular, the association between our measure of equipment imports between $t-2$ and $t$ and productivity growth between $t$ and $t+10$ is positive and

\footnotetext{
${ }^{22}$ The results we report below are robust to replacing eim $_{i t}$ by the share of equipment imports in GDP or by the $\mathrm{R} \& \mathrm{D}$ weighted share of equipment imports in total imports.

${ }^{23}$ We obtain very similar results if instead we control for the degree of trade openness.
} 
significant for poor countries but negative (though insignificant) for rich countries. Columns 1 through 3 and 7 through 9 report the estimated effect of lagged savings on productivity and TFP growth in the subsample for which we have data on equipment imports. The inclusion of equipment imports in the control set reduces by about a third the estimated effect of savings on the average productivity growth of poor countries (column 6). We take this as indication that part of the effect of savings estimated above operates through the import of sophisticated equipment. Interestingly, controlling for equipment imports only reduces the growth effects of savings in poor countries. In rich countries, once we control for equipment imports, the partial correlation between savings and growth increases. The fact that this estimate does not decline, provides further support to the idea that the necessity of savings as collateral to the import of sophisticated equipment holds only when countries are far from the technology frontier. We reach very similar conclusions when the dependent variable in our growth regressions is the average growth rate of TFP between $t$ and $t+10$ (columns 4 through 6$).{ }^{24}$

\section{Conclusion}

In this paper we have developed a theory according to which domestic saving affects economic growth even in a world of capital mobility. The theory is based on the idea that technological progress in relatively poor countries generally requires a mix of foreign investment and local entrepreneurial effort, which effort cannot easily be observed. The foreign investment is needed in order to transfer frontier technological knowledge to local innovating sectors. Saving provides the local entrepreneurs with cofinancing (collateral) which may give local interests enough of a stake in the innovation projects to induce the effort needed to make the foreign investment profitable. The theory predicts that saving should affect growth, but not so much in relatively rich countries that, due to their small distance to the technological frontier, depend less on foreign investment to adopt new technologies. This prediction is borne out by the panel of 118 countries for which we have data on savings over the 1960-2000 period. In this sample we find a strong and robust effect of lagged average savings on productivity growth over the next decade for poor countries but a significantly smaller effect for rich countries. This effect depends entirely on private savings, and operates in part through the increase in FDI and the increase in R\&D intensive equipment imports.

These findings have important implications for various related literatures. First, our hypothesis provides a partial answer to the puzzling slow technology adoption process in developing economies. Second, our model also explains when capital flows to poor countries and therefore it can be used to understand why the overall flows of capital to poor countries are so small. Finally, our model provides a rationale for the high observed correlation between saving and investment in countries that are far from the technology frontier.

The theory and empirical analysis in this paper can be extended in several interesting directions. One is to look at whether the observed relationship between saving and growth

\footnotetext{
${ }^{24}$ After controlling for equipment imports, the coefficient of lagged savings becomes negative and significant. The statistical significance of this coefficient, however, is not robust to controlling for the degree of openness (import plus export share) instead than by the import share.
} 
for poor countries is affected by other variables. For example, is the relationship stronger or weaker in more volatile or in more stable developing economies? Another extension is to develop explanations for the observed differences in saving rates across countries, that would go beyond the differences in their growth rates and the causality from growth to savings. For example, are the low saving rate in Latin America compared to East Asia, due to higher income inequality in Latin America, or to the higher macroeconomic volatility that has characterized this region since the 1980s, or to cultural factors to be unveiled? This and other equally intriguing questions must await further research. 


\section{Appendix}

This appendix describes the baseline models used to explore the reverse causality hypothesis that future growth prospects drive lagged savings. In section 4, we have calibrated two models and run our growth regressions on simulated data. Next we describe these models.

The first is a standard RBC model with CRRA preferences and endogenous labor supply. Specifically, the preferences of the representative consumer are:

$$
U=\sum_{t=0}^{\infty} \beta^{t}\left(\ln \left(c_{t}\right)+\psi\left(1-l_{t}\right)\right)
$$

where $\beta=0.95, \psi=0.35$, and $l_{t}$ is the share of time spend by the consumer working.

The production function is a Cobb-Douglas with capital and labor with standard shares $(1 / 3-2 / 3)$ and TFP is exogenous and its log follows an $\operatorname{AR}(1)$.

In the model with internal habit the consumer supplies labor inelastically and her utility function is:

$$
U=\sum_{t=0}^{\infty} \beta^{t} \frac{\left(c_{t}-\rho c_{t-1}\right)^{1-\sigma}}{1-\sigma},
$$

where $\sigma$ is the coefficient of relative risk aversion and $\rho$ is the habit persistence. The production function now is as follows:

$$
Y_{t}=A_{t} K_{t}^{\alpha} L^{1-\alpha}
$$

where $L$ is fixed, $\alpha$ is calibrated either at $1 / 3$ or at 0.7 and the log of $A_{t}$ follows an $\operatorname{AR}(1)$. 


\section{References}

Aghion, Philippe, and Peter Howitt. "A Model of Growth through Creative Destruction." Econometrica 60 (March 1992): 323-51.

Aghion, Philippe, Marios Angeletos, Abhijit Banerjee and Kalina Manova. "Volatility and

Growth: Credit Constraints and Productivity-Enhancing Investment", mimeo Harvard, 2005.

Aguiar, Mark and Gita, Gopinath. "Emerging Market Business Cycles: The Cycle is the Trend," mimeo Harvard , 2005.

Alfaro, Laura; Kalemli-Ozcan, Sebnem; and V. Volosovych. "Why Doesn't Capital Flow from Rich to Poor Countries? An Empirical Investigation." mimeo Harvard Business School, 2003.

Alfaro, Laura; Chanda, Areendam; Kalemli-Ozcan, Sebnem; and Selin Sayek, "FDI and Economic Growth: The Role of local Financial Markets", Journal of International Economics, 64, (2004): 89-112.

Attanasio, Orazio P., Lucio Picci and Antonello Scurco. "Saving, Growth and Investment: A Macroeconomic Analysis Using a Panel of Countries." The Review of Economics and Statistics, Vol. 82, N0. 2. (May, 2000), pp. 182-211.

Banerjee, Abhijit, and Esther Duflo. "Growth Theory Through the Lens of Development Economics" In Handbook of Economic Growth, edited by Philippe Aghion and Steven N. Durlauf. Amsterdam: North-Holland, forthcoming, 2005.

Bank of Korea, Annual Economic Review, 1955 (Seoul).

Bernanke, Benjamin and Mark Gertler. "Agency Costs, Net Worth, and Business Fluctuations." The American Economic Review, Vol. 79, No. 1. (Mar., 1989), pp. 14-31.

Brown, Gilbert T. Korean Pricing Policies and Economic Development in the 1960s, The John Hopkins University Press (1973).

Carroll, Christopher D., Jody Overland, and David N. Weil. "Saving and Growth with Habit Formation." American Economic Review 90 (June 2000): 341-55.

Carroll, Christopher D., and David N. Weil. "Saving and Growth: A Reinterpretation." Carnegie-Rochester Conference Series on Public Policy 40 (1994): 133-92.

Cass, David, "Optimum Growth in an Aggregative Model of Capital Accumulation", Review of Economic Studies, 32 (1965): 233-240. Chiu, P. C. H. "Money and Financial Markets: the domestic Perspective." in G. Ranis, ed., Taiwan: from Developing to Mature 
Economy. Boulder, CO: Westview, (1992), 121-93.

Clark, Cal. "Taiwan's Financial System: Prosperity from Countervailing Perversities?" in Global Perspectives on Economic Development: Government and Business Finance. Richard Bingham and Edward Hill Eds. Center for Urban and Policy Research, Rutgers, New Jersey, (1997) pp. 116-65.

Comin, Diego, Bart Hobijn and Emilie Rovito. Five Facts You Need to Know about Technology Diffusion" NBER Working Paper No.11928 (2006).

Djankov, Simeon, Caralee McLiesh, and Andrei Shleifer. "Private Credit in 129 Countries." NBER WP\#11078, January 2005.

Domar, E, "Capital Expansion, Rate of Growth, and Employment", Econometrica, 14 (1946): 137-147.

Dooley, M, Folkerts-Landau, D, and P. Garber. "The US Current Account Deficit and Economic Development: Collateral for a Total Return Swap." NBER Working Paper No 10727, 2004.

Frankel, Marvin, "The Production Function in Allocation and Growth: A Synthesis", American Economic Review, 55 (1962): 995-1022.

Frankel, Jeffrey and David Romer, "Does Trade Cause Growth?" American Economic Review, vol. 89 (1999): 379-399.

Gertler, M and K. Rogoff. "North-South Lending and Endogenous Domestic Capital Market Inefficiencies." Journal of Monetary Economics 26 (October 1990): 245-66.

Hall, Robert and Charles Jones. "Why Do Some Countries Produce So Much More Output per Worker than Others?," Quarterly Journal of Economics, February 1999, Vol. 114, pp. 83-116.

Houthakker, Hendrik S. "An International Comparison of Personal Saving." Bulletin of the International Statistical Institute 38 (1961): 55-70.

Houthakker, Hendrik S. "On Some Determinants of Saving in Developed and Underdeveloped Countries." In Problems in Economic Development, edited by E. A. G. Robinson. London: Macmillan, 1965.

Howitt, Peter. "Endogenous Growth and Cross-Country Income Differences." American Economic Review 90 (September 2000): 829-46.

Howitt, Peter, and Philippe Aghion. "Capital Accumulation and Innovation as Complementary Factors in Long-Run Growth." Journal of Economic Growth 3 (June 1998): 
111-30.

Howitt, Peter, and David Mayer-Foulkes. "R\&D, Implementation and Stagnation: A Schumpeterian Theory of Convergence Clubs." Journal of Money, Credit and Banking 37 (February 2005): 147-77.

Hwang, Pyŏng-jun. The Industrial Economy of Korea. Seoul, Korea University, Asiatic Research Center, 1971.

Islam, Nurul. Foreign Capital and Economic Development: Japan, India, and Canada, Prentice-Hall, London, 1960.

Jo, Sung-Hwan "Direct Foreign Private Investment." in Macroeconomic and Industrial development in Korea edited by Chong Kee Park, Korea Development Institute, Seoul, Korea, 1980.

Kim, Kwang Suk. "The Interest-Rate Reform of 1965 and Domestic Saving." Economic Development in the Republic of Korea Lee-Jay Cho and Yoon Hyung Kim Eds. EastWest Center, Hawaii, (1981) pp. 135-162

Kim, Kwang Suk, and Michael Roemer. Growth and Structural Transformation, Harvard East Asian Monographs: 86, Harvard University Press, Cambridge, MA, (1981).

Koopmans, T.C, "On the Concept of Optimal Economic Growth", In The Econometric Approach to Development Planning, Amsterdam: North-Holland, 1965.

Kuznets, Paul. Economic Growth and Structure in the Republic of Korea, New Haven: Yale University Press, 1977.

Levine, Ross, Norman Loyaza, and Thorsten Beck. "Financial Intermediation and Growth: Causality and Causes," Journal of Monetary Economics (2000) 46, 31-77.

Loayza, Norman, Klaus Schmidt-Hebbel and Luis Serven. "What Drives Private Savings Across the World" The Review of Economics and Statistics, Vol. 82, No. 2 (May, 2000), pp. $165-181$

Lucas, Robert E. Jr. "Why doesn't Capital Flow from Rich to Poor Countries?" American Economic Review Papers and Proceedings 80 (May 1990): 92-96.

Mankiw, Gregory, David Romer and David Weil. "A Contribution to the Empirics of Economic Growth." The Quarterly Journal of Economics. Vol. 107, No. 2 (May, 1992), pp. 407-437

Modigliani, Franco. "The Life Cycle Hypothesis of Saving and Inter-Country Differences in the Saving Ratio." In Induction, Growth and Trade: Essays in Honor of Sir Roy Harrod, 
edited by W. A. Eltis. London: Clarendon Press, 1970.

Myers, , R. H. "The Economic Transformation of the Republic of China on Taiwan." China Quarterly, (1984) 99: 500-28.

Nicholas, Henri. "General Observations and Presentation of a few Specific Studies in Ghana and Senegal." Transfer of Technology for Small Industries, OECD Monographs on Technology Transfer, 1974.

Prescott, Edward. "What a Country Must Do to Become Rich" Keynote Address, PREM Conference 2006 and the World Bank.

Reinhart, C, and K. Rogoff. "Serial Default and the "Paradox" of Rich-to-Poor Capital Flows." American Economic Review, Papers and Proceedings 94 (May 2004): 53-58.

Romer, Paul M. "Endogenous Technological Change." Journal of Political Economy 98 (October 1990): S71-S102.

Stallings, B. "The Role of Foreign Capital in economic Development." in G. Gereffi and D.L. Wyman, eds., Manufacturing Miracles: Paths of industrialization in Latin America and East Asia. Princeton: Princeton University Press, (1990), pp. 55-89.

Stock, J. and M. Watson. Introduction to Econometrics, Addison Wesley (2002).

Wade, R. "East asian Financial Systems as a Challange to Economics: Lessons from Taiwan." California Management Review (1985) 27: 106-27.

Westphal, Larry, E. "The Republic of Korea's Experience with Export-led Industrial Development." World Development, 6 (1978), 3, pp. 347-82. 
Table 1: Summary Statistics

\begin{tabular}{|c|c|c|c|c|}
\hline \multirow[t]{2}{*}{ Variable } & \multirow[t]{2}{*}{ Source } & \multicolumn{3}{|c|}{ Sample } \\
\hline & & All & Poor & Rich \\
\hline \multirow[t]{3}{*}{ GDP per worker growth $(t, t+10)$} & Penn World Tables & 0.018 & 0.0147 & 0.0213 \\
\hline & & 0.0259 & 0.0286 & 0.0226 \\
\hline & & 4148 & 2030 & 2118 \\
\hline \multirow[t]{3}{*}{ Growth in $\mathrm{K}$ per woker $(\mathrm{t}, \mathrm{t}+10)$} & Penn World Tables & 0.022 & 0.025 & 0.018 \\
\hline & & 0.041 & 0.047 & 0.033 \\
\hline & & 3230 & 1675 & 1555 \\
\hline \multirow[t]{3}{*}{ Growth in TFP $(t, t+10)$} & Authors' calculations & 0.008 & 0.005 & 0.011 \\
\hline & & 0.021 & 0.023 & 0.016 \\
\hline & & 3230 & 1675 & 1555 \\
\hline \multirow[t]{3}{*}{ Savings/GDP } & Penn World Tables & 0.115 & 0.025 & 0.118 \\
\hline & & 0.168 & 0.161 & 0.2057 \\
\hline & & 5850 & 2935 & 2915 \\
\hline \multirow[t]{3}{*}{ Nominal Savings/GDP } & World Bank & 0.168 & 0.1223 & 0.232 \\
\hline & & 0.145 & 0.156 & 0.098 \\
\hline & & 5022 & 2903 & 2119 \\
\hline \multirow[t]{3}{*}{ Nominal Private savings/GDP } & World Bank & 0.163 & 0.119 & 0.208 \\
\hline & & 0.099 & 0.104 & 0.069 \\
\hline & & 2666 & 1345 & 1321 \\
\hline \multirow[t]{3}{*}{ Nominal Public Savings/GDP } & World Bank & 0.026 & 0.029 & 0.023 \\
\hline & & 0.073 & 0.086 & 0.058 \\
\hline & & 2713 & 1367 & 1346 \\
\hline \multirow[t]{3}{*}{ FDI/GDP } & IMF & 0.019 & 0.017 & 0.022 \\
\hline & & 0.048 & 0.051 & 0.043 \\
\hline & & 3977 & 2319 & 1658 \\
\hline \multirow{3}{*}{$\begin{array}{l}\text { Equipment Imports } \\
\text { adjusted by R\&D content }\end{array}$} & Feenstra, Caselli and Wilson, & 0.002 & 0.001 & 0.0039 \\
\hline & authors' calculations & 0.005 & 0.004 & 0.006 \\
\hline & & 6169 & 3941 & 2228 \\
\hline \multirow[t]{3}{*}{ Private credit/GDP } & Levine, Loayza and Beck (2000) & 0.353 & 0.214 & 0.488 \\
\hline & & 0.308 & 0.188 & 0.34 \\
\hline & & 3602 & 1772 & 1830 \\
\hline
\end{tabular}

For each column and variable, first figure is the average, the second is the standard deviation and the third is the number of observations.

Nominal saving rate denote in domestic prices instead than in international prices. 
Table 2: Savings and Growth

\begin{tabular}{|c|c|c|c|c|c|c|c|c|c|}
\hline Dependent Variable & \multicolumn{3}{|c|}{ Growth GDP/wkr $(t, t+10)$} & \multicolumn{3}{|c|}{ Growth GDP/wkr $(t, t+10)$} & \multicolumn{3}{|c|}{ Growth GDP/wkr $(\mathrm{t}, \mathrm{t}+10)$} \\
\hline $\log$ GDP/wkr t & $\begin{array}{l}-0.039 \\
(12.19)\end{array}$ & $\begin{array}{l}-0.038 \\
(7.54)\end{array}$ & $\begin{array}{l}-0.049 \\
(13.2)\end{array}$ & $\begin{array}{l}-0.038 \\
(11.18)\end{array}$ & $\begin{array}{l}-0.04 \\
(7.57)\end{array}$ & $\begin{array}{l}-0.042 \\
(10.01)\end{array}$ & $\begin{array}{l}-0.042 \\
(12.17)\end{array}$ & $\begin{array}{l}-0.042 \\
(7.51)\end{array}$ & $\begin{array}{l}-0.045 \\
(11.98)\end{array}$ \\
\hline Saving Rate $(\mathrm{t}-4, \mathrm{t})$ & $\begin{array}{l}0.036 \\
(4.09)\end{array}$ & $\begin{array}{l}0.039 \\
(3.08)\end{array}$ & $\begin{array}{c}0.0176 \\
(1.42)\end{array}$ & $\begin{array}{l}0.034 \\
(3.93)\end{array}$ & $\begin{array}{l}0.028 \\
(2.28)\end{array}$ & $\begin{array}{l}0.012 \\
(0.96)\end{array}$ & $\begin{array}{l}0.038 \\
(4.44)\end{array}$ & $\begin{array}{l}0.032 \\
(2.5)\end{array}$ & $\begin{array}{l}0.015 \\
(1.36)\end{array}$ \\
\hline Trade Openness $* 10$ & & & & & & & $\begin{array}{c}0.2 \\
(5.34)\end{array}$ & $\begin{array}{c}0.12 \\
(1.38)\end{array}$ & $\begin{array}{c}0.23 \\
(5.19)\end{array}$ \\
\hline Year*1000 & $\begin{array}{l}-0.01 \\
(0.12)\end{array}$ & $\begin{array}{l}-0.14 \\
(1.12)\end{array}$ & $\begin{array}{c}0.32 \\
(2.92)\end{array}$ & & & & & & \\
\hline Savings Measure & \multicolumn{3}{|c|}{ Penn World Tables } & \multicolumn{3}{|c|}{ Penn World Tables } & \multicolumn{3}{|c|}{ Penn World Tables } \\
\hline $\mathrm{N}$ & 3674 & 1781 & 1893 & 3674 & 1781 & 1893 & 3674 & 1781 & 1893 \\
\hline Sample & All & Poor & Rich & All & Poor & Rich & All & Poor & Rich \\
\hline $\mathrm{R}^{2}$ & 0.31 & 0.23 & 0.42 & 0.33 & 0.27 & 0.47 & 0.35 & 0.28 & 0.51 \\
\hline Year Fixed Effects & No & No & No & Yes & Yes & Yes & Yes & Yes & Yes \\
\hline $\begin{array}{l}\text { Test for equality of s } \\
\text { p-value }\end{array}$ & icients & \multicolumn{2}{|c|}{0.09} & \multicolumn{3}{|c|}{0.2} & \multicolumn{3}{|c|}{0.15} \\
\hline
\end{tabular}

Note: $t$-stats in parenthesis. Errors corrected by Newey-West. All regressions include country dummies.

$\mathrm{R}^{2}$ corresponds to the within $\mathrm{R}^{2}$ from the fixed effects regressions without the error correction

p-value reports the p-value for the test of the null hypothesis that savings has the same effect on growth for rich and poor countries. 
Table 3: Private vs. Public Savings and Growth

\begin{tabular}{|c|c|c|c|c|c|c|c|c|c|}
\hline Dependent Variable & \multicolumn{3}{|c|}{ Growth GDP/wkr $(t, t+10)$} & \multicolumn{3}{|c|}{ Growth GDP/wkr $(\mathrm{t}, \mathrm{t}+10)$} & \multicolumn{3}{|c|}{ Growth GDP/wkr $(t, t+10)$} \\
\hline $\log$ GDP/wkr t & $\begin{array}{l}-0.045 \\
(10.97)\end{array}$ & $\begin{array}{r}-0.049 \\
(8.63)\end{array}$ & $\begin{array}{c}-0.044 \\
(7.42)\end{array}$ & $\begin{array}{c}-0.054 \\
(8.91)\end{array}$ & $\begin{array}{c}-0.076 \\
(8.92)\end{array}$ & $\begin{array}{c}-0.038 \\
(5.6)\end{array}$ & $\begin{array}{c}-0.053 \\
(8.67)\end{array}$ & $\begin{array}{l}0.077 \\
(8.85)\end{array}$ & $\begin{array}{r}-0.039 \\
(5.77)\end{array}$ \\
\hline Nominal Saving Rate $(\mathrm{t}-4, \mathrm{t})$ & $\begin{array}{c}0.03 \\
(2.83)\end{array}$ & $\begin{array}{l}0.046 \\
(2.93)\end{array}$ & $\begin{array}{l}-0.01 \\
(0.88)\end{array}$ & $\begin{array}{l}-0.01 \\
(0.66)\end{array}$ & $\begin{array}{l}0.033 \\
(1.66)\end{array}$ & $\begin{array}{r}-0.027 \\
(1.42)\end{array}$ & & & \\
\hline Private Saving Rate $(\mathrm{t}-4, \mathrm{t})$ & & & & & & & $\begin{array}{l}0.005 \\
(0.32)\end{array}$ & $\begin{array}{l}0.054 \\
(2.97)\end{array}$ & $\begin{array}{c}-0.034 \\
(1.67)\end{array}$ \\
\hline Public Saving Rate $(\mathrm{t}-4, \mathrm{t})$ & & & & & & & $\begin{array}{c}-0.035 \\
(1.7)\end{array}$ & $\begin{array}{r}-0.017 \\
(0.54)\end{array}$ & $\begin{array}{c}-0.012 \\
(0.54)\end{array}$ \\
\hline $\mathrm{N}$ & 2462 & 1272 & 1190 & 1563 & 684 & 879 & 1563 & 684 & 879 \\
\hline Sample & All & Poor & Rich & All & Poor & Rich & All & Poor & Rich \\
\hline $\mathrm{R}^{2}$ & 0.26 & 0.3 & 0.25 & 0.23 & 0.32 & 0.21 & 0.24 & 0.33 & 0.22 \\
\hline \multicolumn{10}{|c|}{ Test for equality of Nominal saving rate/ private saving rate coefficients } \\
\hline
\end{tabular}

Note: Nominal saving rate is saving rate at domestic prices. Private and public saving rate also computed at domestic prices.

$t$-stats in parenthesis. Errors corrected by Newey-West. All regressions include country dummies.

$\mathrm{R}^{2}$ corresponds to the within $\mathrm{R}^{2}$ from the fixed effects regressions without the error correction

p-value reports the p-value for the test of the null hypothesis that private savings has the same effect on growth for rich and poor countries. 
Table 4a: Savings and Growth, Capital Accumulation vs. TFP growth

Dependent Variable

$\log$ GDP/wkr t

Saving Rate $(\mathrm{t}-4, \mathrm{t})$

Year*1000

Savings Measure

$\mathrm{N}$
Sample
$\mathrm{R}^{2}$

\section{Growth GDP/wkr $(t, t+10)$}

Growth K/wkr $(\mathrm{t}, \mathrm{t}+10)$

Growth TFP $(t, t+10)$

$(0.12)$

$\begin{array}{llc}-0.01 & -0.14 & 0.32 \\ (0.12) & (1.12) & (2.92)\end{array}$

Penn World Tables

$\begin{array}{ccc}3674 & 1781 & 1893 \\ \text { All } & \text { Poor } & \text { Rich } \\ 0.31 & 0.23 & 0.42\end{array}$

0.09

Test for equality of savings coefficients

p-value

$-0.032$

$-0.074$

$\begin{array}{ll}-0.034 & -0.036\end{array}$

$-0.03$

$(12.19)$

(8.55)

(4.43)

(10.54)

(12.75)

(9.11)

$\begin{array}{lllllllll}0.036 & 0.039 & 0.0176 & -0.023 & -0.026 & -0.014 & 0.042 & 0.052 & 0.015 \\ (4.09) & (3.08) & (1.42) & (1.61) & (1.48) & (0.62) & (4.87) & (4) & (1.29)\end{array}$

0.08
$(0.56)$

-0.4
$(2.73)$

1.2
$(5.86)$

0.02

$0.06 \quad-0.04$

$(0.36)$

$(0.62)$

$(0.5)$
Penn World Tables

$\begin{array}{ccc}3084 & 1552 & 1532 \\ \text { All } & \text { Poor } & \text { Rich } \\ 0.12 & 0.1 & 0.21\end{array}$

Penn World Tables

$\begin{array}{ccc}3084 & 1552 & 1532 \\ \text { All } & \text { Poor } & \text { Rich } \\ 0.26 & 0.22 & 0.31\end{array}$

Note: t-stats in parenthesis. Errors corrected by Newey-West. All regressions include country dummies.

$\mathrm{R}^{2}$ corresponds to the within $\mathrm{R}^{2}$ from the fixed effects regressions without the error correction

p-value reports the p-value for the test of the null bypothesis that savings bas the same effect on growth for rich and poor countries. 
Table 4b: Savings in domestic prices and Growth, Capital Accumulation vs. TFP growth

\begin{tabular}{|c|c|c|c|c|c|c|c|c|c|}
\hline Dependent Variable & \multicolumn{3}{|c|}{ Growth GDP/wkr $(t, t+10)$} & \multicolumn{3}{|c|}{ Growth $\mathrm{K} / \mathrm{wkr}(\mathrm{t}, \mathrm{t}+10)$} & \multicolumn{3}{|c|}{ Growth TFP $(t, t+10)$} \\
\hline $\log$ GDP/wkr t & $\begin{array}{l}-0.045 \\
(10.97)\end{array}$ & $\begin{array}{c}-0.049 \\
(8.63)\end{array}$ & $\begin{array}{c}-0.044 \\
(7.42)\end{array}$ & $\begin{array}{c}-0.034 \\
(5.21)\end{array}$ & $\begin{array}{c}-0.031 \\
(3.39)\end{array}$ & $\begin{array}{c}-0.062 \\
(7.18)\end{array}$ & $\begin{array}{l}-0.037 \\
(10.25)\end{array}$ & $\begin{array}{r}-0.042 \\
(7.97)\end{array}$ & $\begin{array}{r}-0.027 \\
(6.15)\end{array}$ \\
\hline Nominal Saving Rate $(\mathrm{t}-4, \mathrm{t})$ & $\begin{array}{c}0.03 \\
(2.83)\end{array}$ & $\begin{array}{l}0.046 \\
(2.93)\end{array}$ & $\begin{array}{l}-0.01 \\
(0.88)\end{array}$ & $\begin{array}{c}-0.026 \\
(1.51)\end{array}$ & $\begin{array}{c}-0.038 \\
(1.72)\end{array}$ & $\begin{array}{l}-0.03 \\
(1.31)\end{array}$ & $\begin{array}{l}0.044 \\
(4.07)\end{array}$ & $\begin{array}{l}0.067 \\
(4.05)\end{array}$ & $\begin{array}{l}0.002 \\
(0.11)\end{array}$ \\
\hline Year*1000 & $\begin{array}{l}-0.1 \\
(1.2)\end{array}$ & $\begin{array}{c}-0.3 \\
(2.54)\end{array}$ & $\begin{array}{c}0.27 \\
(2.04)\end{array}$ & $\begin{array}{c}0.02 \\
(0.15)\end{array}$ & $\begin{array}{c}-0.6 \\
(3.94)\end{array}$ & $\begin{array}{c}1.3 \\
(6.28)\end{array}$ & $\begin{array}{l}-0.06 \\
(0.76)\end{array}$ & $\begin{array}{c}0 \\
(0.07)\end{array}$ & $\begin{array}{l}-0.17 \\
(1.64)\end{array}$ \\
\hline Savings Measure & \multicolumn{3}{|c|}{ World Bank } & \multicolumn{3}{|c|}{ World Bank } & \multicolumn{3}{|c|}{ World Bank } \\
\hline $\mathrm{N}$ & 2462 & 1272 & 1190 & 2291 & 1197 & 1094 & 2291 & 1197 & 1094 \\
\hline Sample & All & Poor & Rich & All & Poor & Rich & All & Poor & Rich \\
\hline $\mathrm{R}^{2}$ & 0.26 & 0.3 & 0.25 & 0.08 & 0.12 & 0.19 & 0.22 & 0.22 & 0.22 \\
\hline $\begin{array}{l}\text { Test for equality of savings } \\
\text { p-value }\end{array}$ & cients & \multicolumn{2}{|c|}{$<0.001$} & \multicolumn{3}{|c|}{0.73} & \multicolumn{3}{|c|}{$<0.001$} \\
\hline
\end{tabular}

Note: Nominal saving rate is the saving rate in domestic prices

t-stats in parenthesis. Errors corrected by Newey-West. All regressions include country dummies.

$\mathrm{R}^{2}$ corresponds to the within $\mathrm{R}^{2}$ from the fixed effects regressions without the error correction

p-value reports the p-value for the test of the null hypothesis that savings has the same effect on growth for rich and poor countries. 
Table 5: Savings and Growth, Stock vs. Flow

\begin{tabular}{|c|c|c|c|c|c|c|c|c|c|c|c|c|}
\hline Dependent Variable & \multicolumn{3}{|c|}{ Growth GDP/wkr $(\mathrm{t}, \mathrm{t}+10)$} & \multicolumn{3}{|c|}{ Growth GDP/wkr $(t, t+10)$} & \multicolumn{3}{|c|}{ Growth TFP $(t, t+10)$} & \multicolumn{3}{|c|}{ Growth TFP $(t, t+10)$} \\
\hline $\log$ GDP/wkr t & $\begin{array}{l}-0.039 \\
(12.19)\end{array}$ & $\begin{array}{c}-0.038 \\
(7.54)\end{array}$ & $\begin{array}{c}-0.049 \\
(13.2)\end{array}$ & $\begin{array}{l}-0.045 \\
(11.95)\end{array}$ & $\begin{array}{c}-0.047 \\
(7.98)\end{array}$ & $\begin{array}{l}-0.054 \\
(12.47)\end{array}$ & $\begin{array}{l}-0.034 \\
(12.75)\end{array}$ & $\begin{array}{c}-0.036 \\
(9.11)\end{array}$ & $\begin{array}{l}-0.03 \\
(9.02)\end{array}$ & $\begin{array}{l}-0.035 \\
(12.83)\end{array}$ & $\begin{array}{r}-0.039 \\
(9.39)\end{array}$ & $\begin{array}{r}-0.033 \\
(9.33)\end{array}$ \\
\hline Saving Rate $(\mathrm{t}-4, \mathrm{t})$ & $\begin{array}{l}0.036 \\
(4.09)\end{array}$ & $\begin{array}{l}0.039 \\
(3.08)\end{array}$ & $\begin{array}{c}0.0176 \\
(1.42)\end{array}$ & & & & $\begin{array}{l}0.042 \\
(4.87)\end{array}$ & $\begin{array}{c}0.052 \\
(4)\end{array}$ & $\begin{array}{l}0.015 \\
(1.29)\end{array}$ & & & \\
\hline Saving Rate $(\mathrm{t}-9, \mathrm{t})$ & & & & $\begin{array}{l}0.033 \\
(3.02)\end{array}$ & $\begin{array}{l}0.036 \\
(2.49)\end{array}$ & $\begin{array}{l}0.008 \\
(0.44)\end{array}$ & & & & $\begin{array}{l}0.049 \\
(4.93)\end{array}$ & $\begin{array}{l}0.052 \\
(3.76)\end{array}$ & $\begin{array}{l}0.034 \\
(2.26)\end{array}$ \\
\hline Year*1000 & $\begin{array}{l}-0.01 \\
(0.12)\end{array}$ & $\begin{array}{l}-0.14 \\
(1.12)\end{array}$ & $\begin{array}{c}0.32 \\
(2.92)\end{array}$ & $\begin{array}{c}0.01 \\
(0.16)\end{array}$ & $\begin{array}{l}-0.18 \\
(1.24)\end{array}$ & $\begin{array}{c}0.37 \\
(3.33)\end{array}$ & $\begin{array}{c}0.02 \\
(0.36)\end{array}$ & $\begin{array}{c}0.06 \\
(0.62)\end{array}$ & $\begin{array}{c}-0.04 \\
(0.5)\end{array}$ & $\begin{array}{l}0.056 \\
(0.77)\end{array}$ & $\begin{array}{l}0.096 \\
(0.86)\end{array}$ & $\begin{array}{c}0.03 \\
(0.35)\end{array}$ \\
\hline Savings Measure & Per & World ${ }^{\prime}$ & bles & Pen & World ${ }^{2}$ & bles & Pen & World T & ples & Pent & World 'T & ples \\
\hline $\mathrm{N}$ & 3674 & 1781 & 1893 & 3089 & 1476 & 1613 & 3084 & 1552 & 1532 & 2869 & 1373 & 1496 \\
\hline Sample & All & Poor & Rich & All & Poor & Rich & All & Poor & Rich & All & Poor & Rich \\
\hline $\mathrm{R}^{2}$ & 0.31 & 0.23 & 0.42 & 0.3 & 0.27 & 0.37 & 0.26 & 0.22 & 0.31 & 0.27 & 0.22 & 0.32 \\
\hline \multicolumn{13}{|c|}{ Test for equality of savings coefficients } \\
\hline
\end{tabular}

Note: t-stats in parenthesis. Errors corrected by Newey-West. All regressions include country dummies.

$\mathrm{R}^{2}$ corresponds to the within $\mathrm{R}^{2}$ from the fixed effects regressions without the error correction

p-value reports the p-value for the test of the null hypothesis that savings has the same effect on growth for rich and poor countries. 
Table 6: Reverse Causality?

\begin{tabular}{|c|c|c|c|c|c|c|c|c|}
\hline & Model & habit & autocorrelation & risk aver. & k-share & effect of savings on Y/L growth & effect of savings on TFP growth & $\operatorname{std}(\mathrm{I}) / \operatorname{std}(\mathrm{Y})$ \\
\hline 1 & $\mathrm{RBC}$ & - & 0.8 & 3 & 0.33 & $\begin{array}{c}1.75 \mathrm{E}-05 \\
(1.9992 \mathrm{e}-006,3.2990 \mathrm{e}-005)\end{array}$ & $\begin{array}{c}2.98 \mathrm{E}-06 \\
(-4.0253 \mathrm{e}-006,9.9934 \mathrm{e}-006)\end{array}$ & $\begin{array}{c}3.6958 \\
(3.6915,3.7)\end{array}$ \\
\hline 2 & RBC & - & 0.95 & 3 & 0.33 & $\begin{array}{c}3.80 \mathrm{E}-04 \\
(1.7423 \mathrm{e}-004,5.8542 \mathrm{e}-004)\end{array}$ & $\begin{array}{c}1.75 \mathrm{E}-04 \\
(1.0353 \mathrm{e}-005,3.3871 \mathrm{e}-004)\end{array}$ & $\begin{array}{c}3.1175 \\
(3.1135,3.1214)\end{array}$ \\
\hline 3 & Habit & 0.8 & 0.8 & 3 & 0.33 & $\begin{array}{c}-0.0054 \\
(-0.0072,-0.0037)\end{array}$ & $\begin{array}{c}0.0083 \\
(0.0067,0.0098)\end{array}$ & $\begin{array}{c}3.2192 \\
(3.2178,3.2206)\end{array}$ \\
\hline 4 & Habit & 0.8 & 0.95 & 3 & 0.33 & $\begin{array}{c}-0.0363 \\
(-0.0433,-0.0293)\end{array}$ & $\begin{array}{c}-0.0039 \\
(-0.0098,0.0019)\end{array}$ & $\begin{array}{c}1.6706 \\
(1.6704,1.6709)\end{array}$ \\
\hline 5 & Habit & 0.8 & 0.8 & 3 & 0.7 & $\begin{array}{c}-0.0024 \\
(-0.0074,0.027)\end{array}$ & $\begin{array}{c}0.0312 \\
(0.0269,0.0355)\end{array}$ & $\begin{array}{c}1.778 \\
(1.7775,1.778)\end{array}$ \\
\hline 6 & Habit & 0.8 & 0.5 & 3 & 0.7 & $\begin{array}{c}-0.0055 \\
(-0.0086,-0.0024)\end{array}$ & $\begin{array}{c}0.0209 \\
(0.018,0.0238)\end{array}$ & $\begin{array}{c}2.1124 \\
(2.1119,2.1130)\end{array}$ \\
\hline 7 & Habit & 0.95 & 0.8 & 3 & 0.33 & $\begin{array}{c}-0.0064 \\
(-0.0077,-0.0051)\end{array}$ & $\begin{array}{c}0.0099 \\
(0.0087,0.011)\end{array}$ & $\begin{array}{c}3.7958 \\
(3.7949,3.7967)\end{array}$ \\
\hline 8 & Habit & 0.95 & 0.8 & 3 & 0.7 & $\begin{array}{c}-0.0172 \\
(-0.0218,-0.0126)\end{array}$ & $\begin{array}{c}0.0297 \\
(0.0259,0.0334)\end{array}$ & $\begin{array}{c}1.8692 \\
(1.8688,1.8695)\end{array}$ \\
\hline 9 & Habit & 0.95 & 0.5 & 3 & 0.7 & $\begin{array}{c}-0.0106 \\
(-0.0134,-0.0078)\end{array}$ & $\begin{array}{c}0.02 \\
(0.0173,0.0227)\end{array}$ & $\begin{array}{c}2.164 \\
(2.1636,2.1644)\end{array}$ \\
\hline
\end{tabular}

Each line correspond to a calibration of either a standard RBC model or a model with internal habit. Columns 2-6 describe calibration. Columns 7 and 8 report the average estimate of the effect of lagged savings on productivity (7) and TFP growth (8) and its 95 percent confidence interval for the model calibration. Column 9 contains the average of the ratio of the standard deviation of the H-P filtered investment to the standard deviation of the H-P filtered output across the simulations and the 95 percent confidence interval for the ratio. 
Table 7: Private Savings, Financial Development and Growth

\begin{tabular}{|c|c|c|c|c|c|c|c|c|c|c|c|c|}
\hline Dependent Variable & \multicolumn{3}{|c|}{ Growth GDP/wkr $(t, t+10)$} & \multicolumn{3}{|c|}{ Growth GDP/wkr $(t, t+10)$} & \multicolumn{3}{|c|}{$\operatorname{TFP}(t, t+10)$} & \multicolumn{3}{|c|}{$\operatorname{TFP}(t, t+10)$} \\
\hline $\log$ GDP/wkr t & $\begin{array}{r}-0.049 \\
(8.95)\end{array}$ & $\begin{array}{r}-0.061 \\
(6.85)\end{array}$ & $\begin{array}{c}-0.037 \\
(5.1)\end{array}$ & $\begin{array}{r}-0.049 \\
(8.95)\end{array}$ & $\begin{array}{c}-0.061 \\
(7.47)\end{array}$ & $\begin{array}{r}-0.045 \\
(5.43)\end{array}$ & $\begin{array}{c}-0.039 \\
(7.91)\end{array}$ & $\begin{array}{c}-0.043 \\
(5.37)\end{array}$ & $\begin{array}{r}-0.031 \\
(4.71)\end{array}$ & $\begin{array}{r}-0.039 \\
(7.91)\end{array}$ & $\begin{array}{c}-0.04 \\
(6.1)\end{array}$ & $\begin{array}{c}-0.029 \\
(3.8)\end{array}$ \\
\hline Private Saving/GDP $(\mathrm{t}-4, \mathrm{t})$ & $\begin{array}{c}0 \\
(0.15)\end{array}$ & $\begin{array}{l}0.055 \\
(2.94)\end{array}$ & $\begin{array}{c}-0.045 \\
(2.41)\end{array}$ & $\begin{array}{c}0 \\
(0.15)\end{array}$ & $\begin{array}{c}-0.016 \\
(0.85)\end{array}$ & $\begin{array}{l}0.031 \\
(1.31)\end{array}$ & $\begin{array}{c}0.01 \\
(0.52)\end{array}$ & $\begin{array}{l}0.059 \\
(2.85)\end{array}$ & $\begin{array}{l}-0.03 \\
(1.59)\end{array}$ & $\begin{array}{c}0.01 \\
(0.52)\end{array}$ & $\begin{array}{c}-0.008 \\
(0.37)\end{array}$ & $\begin{array}{c}0.04 \\
(1.69)\end{array}$ \\
\hline Year*1000 & $\begin{array}{c}0.77 \\
(6.38)\end{array}$ & $\begin{array}{l}0.23 \\
(1.1)\end{array}$ & $\begin{array}{l}0.9 \\
(7)\end{array}$ & $\begin{array}{c}0.77 \\
(6.38)\end{array}$ & $\begin{array}{c}0.4 \\
(1.95)\end{array}$ & $\begin{array}{c}1 \\
(6.22)\end{array}$ & $\begin{array}{c}0.47 \\
(4.03)\end{array}$ & $\begin{array}{c}0.22 \\
(0.95)\end{array}$ & $\begin{array}{c}0.5 \\
(4.19)\end{array}$ & $\begin{array}{c}0.47 \\
(4.03)\end{array}$ & $\begin{array}{c}0.5 \\
(2.65)\end{array}$ & $\begin{array}{c}0.27 \\
(1.71)\end{array}$ \\
\hline $\begin{array}{l}\mathrm{N} \\
\text { Sample }\end{array}$ & $\begin{array}{c}1222 \\
\text { All }\end{array}$ & $\begin{array}{l}498 \\
\text { Poor }\end{array}$ & $\begin{array}{r}724 \\
\text { Rich }\end{array}$ & $\begin{array}{c}1222 \\
\text { All }\end{array}$ & $\begin{array}{r}600 \\
\mathrm{LFD}\end{array}$ & $\begin{array}{c}622 \\
\text { HFD }\end{array}$ & $\begin{array}{c}1195 \\
\text { All }\end{array}$ & $\begin{array}{l}486 \\
\text { Poor }\end{array}$ & $\begin{array}{r}709 \\
\text { Rich }\end{array}$ & $\begin{array}{c}1195 \\
\text { All }\end{array}$ & $\begin{array}{r}589 \\
\mathrm{LFD}\end{array}$ & $\begin{array}{c}603 \\
\mathrm{HFD}\end{array}$ \\
\hline $\mathrm{R}^{2}$ & 0.18 & 0.2 & 0.2 & 0.18 & 0.24 & 0.16 & 0.13 & 0.11 & 0.14 & 0.13 & 0.15 & 0.1 \\
\hline $\begin{array}{l}\text { Test for equality of savings } \\
\text { p-value }\end{array}$ & icients & & & & & & & & & & & \\
\hline
\end{tabular}

Note: All samples restricted to country-year observations with data on private credit.

LFD (low financial development) are countries with private credit to GDP ratio below the median ratio in the year.

$H D F$ (bigh financial development) are countries with private credit to GDP ratios above the median ratio in the year.

t-stats in parenthesis. Errors corrected by Newey-West. All regressions include country dummies.

$\mathrm{R}^{2}$ corresponds to the within $\mathrm{R}^{2}$ from the fixed effects regressions without the error correction

p-value reports the p-value for the test of the null hypothesis that savings has the same effect on growth for high and low financially developed countries. 
Table 8: FDI and Savings

\begin{tabular}{|c|c|c|c|c|c|c|c|c|c|}
\hline Dependent Variable & \multicolumn{3}{|c|}{ FDI/GDP $(\mathrm{t}-2, \mathrm{t})$} & \multicolumn{3}{|c|}{ FDI/GDP $(\mathrm{t}-2, \mathrm{t})$} & \multicolumn{3}{|c|}{ FDI/GDP $(\mathrm{t}-2, \mathrm{t})$} \\
\hline Saving Rate $(\mathrm{t}-4, \mathrm{t})$ & $\begin{array}{c}0.12 \\
(3.44)\end{array}$ & $\begin{array}{c}0.14 \\
(2.61)\end{array}$ & $\begin{array}{c}0.1 \\
(3.61)\end{array}$ & $\begin{array}{c}0.11 \\
(2.95)\end{array}$ & $\begin{array}{c}0.11 \\
(2.04)\end{array}$ & $\begin{array}{c}0.14 \\
(4.85)\end{array}$ & $\begin{array}{l}0.11 \\
(2.9)\end{array}$ & $\begin{array}{c}0.11 \\
(2.16)\end{array}$ & $\begin{array}{c}0.13 \\
(4.55)\end{array}$ \\
\hline $\log$ GDP/wkr t-3 & & & & $\begin{array}{c}-0.018 \\
(2.67)\end{array}$ & $\begin{array}{r}-0.016 \\
(2.44)\end{array}$ & $\begin{array}{c}-0.019 \\
(2.69)\end{array}$ & $\begin{array}{c}-0.015 \\
(2.87)\end{array}$ & $\begin{array}{c}-0.017 \\
(2.7)\end{array}$ & $\begin{array}{r}-0.022 \\
(2.71)\end{array}$ \\
\hline Trade Openness $(\mathrm{t}-3) * 10$ & & & & & & & $\begin{array}{c}0.18 \\
(4.18)\end{array}$ & $\begin{array}{c}0.2 \\
(3.86)\end{array}$ & $\begin{array}{c}0.21 \\
(3.48)\end{array}$ \\
\hline Year*1000 & $\begin{array}{c}1 \\
(9.24)\end{array}$ & $\begin{array}{c}0.92 \\
(5.45)\end{array}$ & $\begin{array}{c}1.02 \\
(6.52)\end{array}$ & $\begin{array}{c}1.1 \\
(8.21)\end{array}$ & $\begin{array}{c}0.87 \\
(5.11)\end{array}$ & $\begin{array}{c}1.3 \\
(6.4)\end{array}$ & $\begin{array}{c}0.96 \\
(6.47)\end{array}$ & $\begin{array}{c}0.7 \\
(3.25)\end{array}$ & $\begin{array}{c}1.3 \\
(6.04)\end{array}$ \\
\hline $\begin{array}{l}\mathrm{N} \\
\text { Sample }\end{array}$ & $\begin{array}{c}2905 \\
\text { All }\end{array}$ & $\begin{array}{l}1520 \\
\text { Poor }\end{array}$ & $\begin{array}{l}1385 \\
\text { Rich }\end{array}$ & $\begin{array}{c}2702 \\
\text { All }\end{array}$ & 1431 & $\begin{array}{l}1271 \\
\text { Rich }\end{array}$ & $\begin{array}{c}2702 \\
\text { All }\end{array}$ & 1431 & $\begin{array}{l}1271 \\
\text { Rich }\end{array}$ \\
\hline $\mathrm{R}^{2}$ & 0.09 & 0.08 & 0.12 & 0.14 & 0.14 & 0.15 & 0.15 & 0.16 & 0.16 \\
\hline
\end{tabular}

Note: $t$-stats in parenthesis. Errors corrected by Newey-West. All regressions include country dummies.

$\mathrm{R}^{2}$ corresponds to the within $\mathrm{R}^{2}$ from the fixed effects regressions without the error correction 
Table 9: Savings, FDI and Growth

\begin{tabular}{|c|c|c|c|c|c|c|}
\hline \multirow{2}{*}{$\begin{array}{l}\text { Dependent Variable } \\
\log \text { GDP/wkr t }\end{array}$} & \multicolumn{3}{|c|}{ Growth GDP/wkr $(t, t+10)$} & \multicolumn{3}{|c|}{ Growth TFP $(t, t+10)$} \\
\hline & $\begin{array}{l}-0.065 \\
(11.94)\end{array}$ & $\begin{array}{l}-0.061 \\
(8.67)\end{array}$ & $\begin{array}{c}-0.066 \\
(9.46)\end{array}$ & $\begin{array}{l}-0.051 \\
(12.15)\end{array}$ & $\begin{array}{c}-0.048 \\
(9)\end{array}$ & $\begin{array}{c}-0.048 \\
(7.09)\end{array}$ \\
\hline Saving Rate $(\mathrm{t}-4, \mathrm{t})$ & $\begin{array}{l}0.022 \\
(1.84)\end{array}$ & $\begin{array}{l}0.014 \\
(0.82)\end{array}$ & $\begin{array}{l}0.009 \\
(0.55)\end{array}$ & $\begin{array}{l}0.036 \\
(3.03)\end{array}$ & $\begin{array}{l}0.043 \\
(2.39)\end{array}$ & $\begin{array}{l}0.013 \\
(0.83)\end{array}$ \\
\hline FDI $(\mathrm{t}-2, \mathrm{t})$ & $\begin{array}{c}0.09 \\
(2.08)\end{array}$ & $\begin{array}{c}0.13 \\
(2.23)\end{array}$ & $\begin{array}{l}0.035 \\
(0.58)\end{array}$ & $\begin{array}{c}0.07 \\
(1.95)\end{array}$ & $\begin{array}{c}0.09 \\
(1.63)\end{array}$ & $\begin{array}{l}0.049 \\
(0.84)\end{array}$ \\
\hline Year*1000 & $\begin{array}{c}0.3 \\
(2.62)\end{array}$ & $\begin{array}{l}-0.2 \\
(1.3)\end{array}$ & $\begin{array}{c}0.9 \\
(6.32)\end{array}$ & $\begin{array}{c}0.37 \\
(3.54)\end{array}$ & $\begin{array}{c}0.2 \\
(1.33)\end{array}$ & $\begin{array}{c}0.5 \\
(3.97)\end{array}$ \\
\hline $\begin{array}{l}\mathrm{N} \\
\text { Sample }\end{array}$ & $\begin{array}{c}1847 \\
\text { All }\end{array}$ & $\begin{array}{c}951 \\
\text { Poor }\end{array}$ & $\begin{array}{l}896 \\
\text { Rich }\end{array}$ & $\begin{array}{c}1714 \\
\text { All }\end{array}$ & $\begin{array}{l}898 \\
\text { Poor }\end{array}$ & $\begin{array}{r}816 \\
\text { Rich }\end{array}$ \\
\hline $\mathrm{R}^{2}$ & 0.28 & 0.29 & 0.3 & 0.23 & 0.21 & 0.2 \\
\hline
\end{tabular}

Note: t-stats in parenthesis. Errors corrected by Newey-West. All regressions include country dummies. $\mathrm{R}^{2}$ corresponds to the within $\mathrm{R}^{2}$ from the fixed effects regressions without the error correction 
Table 10: Equipment Imports in GDP and Savings

Dependent Variable

Savings Rate $(\mathrm{t}-4, \mathrm{t}) * 100$

Imports/GDP (t-2,t)

$\log$ GDP/wkr t-3*100

Year*1000

$\mathrm{N}$

Sample

$\mathrm{R}^{2}$

$\begin{array}{ccc}-0.13 & -0.1 & -0.14 \\ (9.01) & (5.21) & (7.19) \\ & & \\ 2021 & 786 & 1235 \\ \text { All } & \text { Poor } & \text { Rich } \\ 0.12 & 0.19 & 0.11\end{array}$

$0.012 \quad 0.015$

0.011

(4.72)

(6.96)

$(4.95)$
Equipment imports weighted by R\&D/GDP $(\mathrm{t}-2, \mathrm{t}$

$\begin{array}{cccccc}-0.42 & 0.85 & -1.1 & -0.46 & 0.84 & -1.2 \\ (1.13) & (2.57) & (1.89) & (1.31) & (2.42) & (2.21)\end{array}$

0.012

(6.55)

0.016

0.01

0.3

(5.1)

(4.3)

(0.49)

$-0.01$

0.14

$(0.09)$

$-0.13$

$-0.1$

$-0.17$

(9.25)

(3.63)

(8.1)

1990

776

1214

All

Poor

Rich

0.11

0.2

0.1

Note: -stats in parenthesis. Errors corrected by Newey-West. All regressions include country dummies.

$\mathrm{R}^{2}$ corresponds to the within $\mathrm{R}^{2}$ from the fixed effects regressions without the error correction 
Table 11: Savings, equipment share in imports and Growth

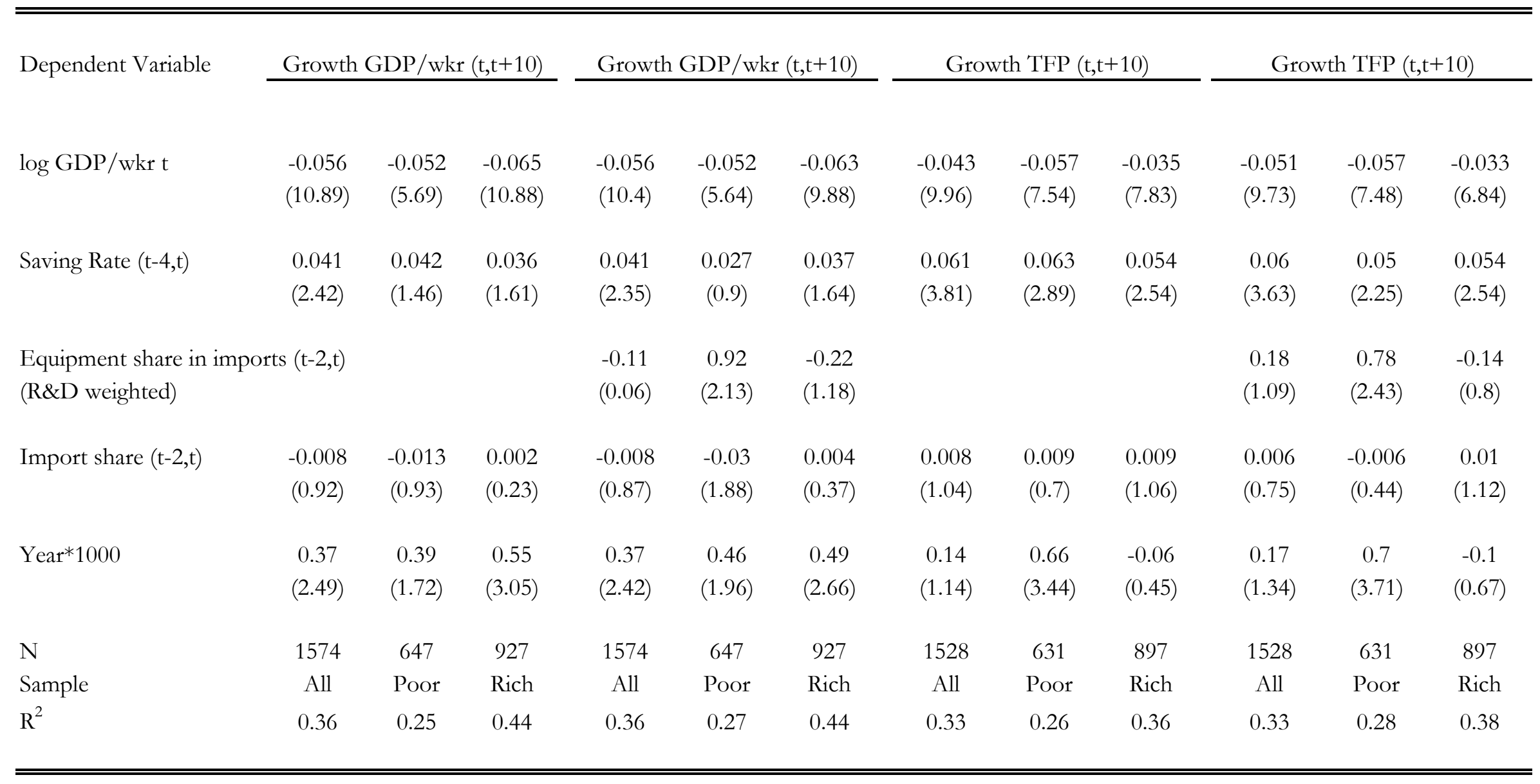

Note: The samples are restricted to the countries for which we have data on Equipment share in imports between $t-2$ and $t$, weighted by the R\&D content of the imports. t-stats in parenthesis. Errors corrected by Newey-West. All regressions include country dummies.

$\mathrm{R} 2$ corresponds to the within $\mathrm{R} 2$ from the fixed effects regressions without the error correction 